ISSN:2528-9527

E-ISSN : 2528-9535

YII Year: 11

Cilt Volume: 18

Sayı Issue: Eğitim Bilimleri Özel Sayısı

Eylül September 2021

Uluslararası Toplum Araştırmaları Dergisi International Journal of Society Researches

Makalenin Geliş Tarihi Received Date: 30/03/2021 Makalenin Kabul Tarihi Accepted Date: 03/06/2021

\title{
Lise Öğrencilerinde Öz-Şefkat ile Duygusal Özerklik Arasındaki İlişkide Erken Dönem Uyumsuz Şemaların Aracı Rolï ${ }^{1}$
}

\author{
DOI: 10.26466/opus.906143 \\ $*$ \\ Lokman Koçak* - Eyüp Çelik ** \\ * Dr., Sakarya Üniversitesi, Eğitim Bilimleri Enstitüsü, Sakarya/Türkiye \\ E-Posta: lokmankocak@sakarya.edu.tr \\ ORCID: $\quad$ 0000-0002-5247-0974 \\ ** Doç. Dr., Sakarya Üniversitesi, Eğitim Fakültesi, Sakarya/Türkiye \\ E-Posta: eyupcelik@sakarya.edu.tr \\ ORCID: $\underline{0000-0002-7714-9263}$
}

\begin{abstract}
Öz
$B u$ araştırmanın amacl, lise öğrencilerinde öz-şefkat ile duygusal özerklik arasındaki ilişkide erken dönem uyumsuz şemaların aracı rolünün incelenmesidir. Araştırmanın çalışma grubu, 2019-2020 eğitim-öğretim yılında Kocaeli ilinde öğrenim görmekte olan 296 kadın (\%53.2) ve 260 erkek (\%46.8) olmak üzere toplam 556 lise öğrencisinden oluşmaktadır. Yaşları 14 ile 16 yaş arasında değişen katılımcıların yaş ortalaması 15.2'dir. Araştırmanın verileri; "Ergenler için Duygusal Özerklik Ölçeği", "Ergenler için Öz-Şefkat Ölçeği" ve 10-16 Yas, Çocuk ve Ergenler için Erken Dönem Uyumsuz Şema Ölçekler Takımı ile toplanmıştır. Araştırmada öz-şefkat, duygusal özerklik ve erken dönem uyumsuz şemalar arasındaki ilişkiler regresyona dayalı aracılık analizi ve korelasyon analizi ile incelenmiştir. Ayrıca, test edilmeye çalışılan aracı modeldeki doğrudan ve dolaylı etkiler bootstrap yöntemi ile belirlenmiştir. İlgili alanyazın ışığında, şema alanları dikkate alınarak aracılık modelleri kurulmuş ve bu doğrultuda erken dönem uyumsuz şemaların aracı rolü sınanmıştır. Araştırma sonucunda erken dönem uyumsuz şemaların öz-şefkat ile duygusal özerklik arasındaki ilişkide aracılık etkisine sahip olduğu tespit edilmiştir. Elde edilen sonuçlar ilgili alanyazın bağlamında tartışılmıştır.
\end{abstract}

Anahtar Kelimeler: Ergenlik, duygusal özerklik, öz-şefkat, erken dönem uyumsuz şemalar.

\footnotetext{
${ }^{1}$ Bu çalışma birinci yazarın, ikinci yazar danışmanlığında yürütülen doktora tezinden üretilmiştir. 


\title{
The Mediating Role of Early Maladaptive Schemas in the Relationship between Self-Compassion and Emotional Autonomy in High School Students
}

$*$

\begin{abstract}
The aim of this study is to examine the mediating role of early maladaptive schemas in the relationship between self-compassion and emotional autonomy in high school students. The study group consists of a total of 556 high school students, 296 female (53.2\%) and 260 male (46.8\%), who were studying at different high schools in Kocaeli province in 2019-2020 academic year. The participants were aged between 14 and 16, with an average age of 15.2. As data collecting tools, "Emotional Autonomy Scale for Adolescents", "The Self-Compassion Scale for Adolescents" and "Early Maladaptive Schema Questionnaires Set for Children and Adolescents between the Ages of 10-16" were used. In the study, the relationships between self-compassion, emotional autonomy, and early maladaptive schemas were examined using regression-based mediation analysis and correlation analysis. Furthermore, a bootstrap method was used to examine the direct and indirect effects in the mediation model. According to the relevant literature, mediation models were established by taking the schema areas into consideration, and the mediating role of early maladaptive schemas was tested accordingly. The findings showed that early maladaptive schemas has a mediating effect on the relationship between self-compassion and emotional autonomy. The findings obtained are discussed in the context of the relevant literature.
\end{abstract}

Key Words: Adolescence, emotional autonomy, self-compassion, early maladaptive schemas. 


\section{Giriş}

İnsan yaşamında önemli gelişim dönemlerinden biri ergenliktir. Gelişimdeki en hızlı iki büyüme evresinden birini oluşturan ergenlik, biyolojik değişimle başlayıp, bedensel, zihinsel ve duygusal gelişimle tamamlanmaktadır (Yavuzer, 2000). Çocukluktan yetişkinliğe geçişte bir köprü niteliğinde olan ergenlik dönemi, bireye daha az sınır ve bu zamana kadarki deneyimlerine göre çok daha fazla özgürlük sunmaktadır. Beden ve zihindeki değişikliklerle birlikte ergende yeni bedensel duyular ve yeni davranış örüntüleri oluşmaya başlamaktadır (Loose, Graaf ve Zarbock, 2018). Çevrenin bu yeniliklere tepki göstermesi, ergende kafa karışıklığına yol açmakta ve ergenin içsel ve dışsal çatışmalar yaşamasına neden olmaktadır (Bektaş, 2004). Bu süreç ergenin diğer insanlar tarafından beğenilme ve çekici bulunma gibi konularda kendini sürekli sorgulaması ve ergenin akran grupları tarafından kabul görme isteğinin artması ile devam etmektedir (Paxton, Schutz, Wertheim ve Muir, 1999). Bütün bu çatışmalar ergenlik dönemini ergen ve ebeveynler için zor, heyecanlı ve kaygıyla dolu bir sürece dönüştürürken; aynı zamanda ergenin olgunlaşmasına da aracılık etmektedir (Plotnik, 2009).

Ergenlik dönemi, tamamlanması gereken bir dizi gelişim göreviyle birlikte karmaşık ve zor bir süreçtir (Loose vd., 2018). Ergen bireyler bir yandan akranlarla yakın ilişkiler kurma, kariyer planları yapma, kimlik kazanma ve ebeveynlerden ayrışma (Loose vd., 2018; Steinberg, 2013) gibi çok sayıda gelişim görevini tamamlamaya çalışırken; bir yandan da okuldaki görev ve sorumluluklarını aksatmamak için çaba göstermektedir. Bu zorlu süreç, ergenlerin içsel ve dişsal sorunlar yaşamasına ve psikolojik sağlığının olumsuz yönde etkilenmesine neden olmaktadır. Yapılan araştırmalar, lise öğrencilerinin okul tükenmişliği (Koçak ve Seçer, 2018), akademik stres (Kutsal ve Bilge, 2012), depresyon (Burwell ve Shirk, 2006), kayg1 (Özyürek ve Demiray, 2010) ve zorbalığa maruz kalma (Ayas ve Pişkin, 2011) gibi sorunlar yaşadığını göstermektedir. Lise öğrencilerinin yaşadıkları sorunlarla baş edebilmesine ve bu süreci sağlıklı bir şekilde atlatabilmesine katkı sağlayacak kavramlardan birinin duygusal özerklik olabileceği söylenebilir. Bu dönemde daha çok kendine yetme ve özgür olma 
ihtiyacı hisseden bireyin; duygusal özerklikle birlikte kendi kararlarını almaya ve duygu ve davranışlarını yönetmeye başladığı belirtilmektedir (Zimmer-Gembeck ve Collins, 2006). Ayrıca, kimlik arayışı, kendi benliğini oluşturma ve sosyal etkileşimlerin artmasında özerklik gelişiminin etkili olduğu öne sürülmektedir (Deniz, Çok ve Duyan, 2013). Bu doğrultuda, özellikle duygusal bağımsızlık kazanma, bireyleşme ve akranlar ve sosyal çevreyle ilişkiler kurma gibi kritik gelişim görevlerinin başarıyla tamamlanmasında, duygusal özerkliğin önemli bir rolü olduğu düşünülebilir.

Yetişkinlik yolunda ergenin kazanması gereken bir beceri olarak açıklanan özerklik (Steinberg, 2013); ergenlerin aileleri, akranları ve çevrelerindeki diğer kişilerle kurduğu ilişkiler yoluyla gelişmektedir (Russell ve Bakken, 2002). Kimlik arayışı, kendi benliğini oluşturma çabaları, artan sosyal etkileşimler ve yeni görev ve sorumluluklar özerkliğin gelişimini hızlandırmaktadır (Deniz vd., 2013). Bu dönemde daha çok kendine yetme ve özgür olma ihtiyacı hisseden birey; özerklikle birlikte kendi kararlarını almaya ve duygu ve davranışlarını yönetmeye başlamaktadır (Zimmer-Gembeck ve Collins, 2006).

Özerkliği davranışsal özerklik, değer özerkliği ve duygusal özerklik olarak üçe ayıran Steinberg (2013), duygusal özerkliğin bireyin özellikle ailesi ile olan yakın ilişkilerdeki değişimlerle ilgili bağımsızlığı içerdiğini belirtmiştir. Ergenin, ebeveyn ve akranlarından duygusal anlamda bağımsızlaşabilmesinin duyusal süreci olarak ifade edilen duygusal özerklik; ergenin ana-baba ve çevresindeki diğer kişilerin istek ve beklentileri dışında kendi istek ve amaçlarını tanımlaması ve kendine güven duymasıyla gelişmektedir (Noom, Dekovic ve Meeus, 2001). Duygusal özerklik; ebeveynleri idealleştirmeme, ebeveyni bir birey olarak görme, bağımsızlık ve bireyleşme şeklinde dört boyut olarak ifade edilmektedir (Steinberg ve Silverberg, 1986). Duygusal özerklik; ana babaya olan bağımlılı̆̆ın terk edilmesi ve onlardan ayrı bir birey olmanın fark edilmesi olarak ifade edilebilir. Duygusal özerkliğin gelişimiyle birlikte ergen, önceden idealleştirdiği ve her şeyi bilen, yanılmayan ebeveyn algısını yavaş yavaş değiştirmeye başlar ve daha olgun bir kavrayış ile ebeveynlerini bir insan olarak değerlendirir. Ergenlik dönemi boyunca giderek artan duygusal özerklik, ergenin büyümesine ve ebeveyn denetiminden daha fazla bağımsızlık elde 
etmek için çabalamasına olanak tanımaktadır. Bu büyüme ve bireyleşme ile birlikte ebeveynlerin idealleştirilmesi azalırken; onlara olan çocukça bağımlılıklar daha az dile getirilmektedir (Tatar, Bildik, Yektaş, Hamidi ve Özmen, 2016).

Duygusal özerkliğin, akademik başarı (Chen ve Dornbusch, 1998), öznel iyi oluş ve algılanan sosyal destek (Erçevik, 2014; Güney, 2017) gibi değişkenlerle pozitif yönlü ilişkili olduğu saptanmıştır. Duygusal özerkliğe sahip bireylerin daha olgun ve sorumluluk sahibi olduğu ve daha az bağımlı ilişkiler kurduğu belirtilmektedir (Steinberg, 2013). Ayrıca sağlıklı özerklik gelişiminin ergenlere, madde kullanımı ve suça sürüklenme gibi riskli davranışlardan korunma ve iş yaşamında üst hedeflere ulaşma konusunda avantaj sağlayacağ1 düşünülmektedir (Özdemir ve Çok, 2011). Bu doğrultuda duygusal özerkliğin, ergenlik dönemi için önemli bir kavram olduğu ve farklı değişkenlerle incelenmesinin, duygusal özerklik gelişiminde etkili olan faktörlerin belirlenmesine katkı sağlayacağı düşünülebilir.

Ergen bireyin ana babadan ayrışmasının, kaçınılmaz bir gelişim görevi olduğu ifade edilmektedir (Loose vd., 2018). Bu ayrışmanın sağlıklı şekilde gerçekleşebilmesi için ebeveynlerin, ergenin özerklik isteğini kolaylaştırması ve ayrışma ihtiyacına karşı anlayışlı olması gerekmektedir. Bireylerin, ilişkisel desteğe ek olarak öz-desteğe de ihtiyaç duyduğu belirtilmektedir (Vatan, 2019). Bir başa çıma stratejisi olarak kullanılan öz-şefkatin, söz konusu öz-desteği sağlayacağ1 düşünülebilir. Özellikle acı veren duygularla nazikçe ilgilenip onların olumsuz etkilerini azalttığ oldukça etkili olduğu ifade edilen öz-şefkatin (Germer, 2020), ergenlerin duygusal olgunluğa erişmesi, akran ve ebeveyn baskılarına karşı koyabilmesi ve kişiler arası ilişkilerde yeterlik kazanması (Noom vd., 2001) gibi becerileri içeren duygusal özerklik gelişimine olumlu etki edeceği söylenebilir.

Öz-şefkat, bireyin yetersizlik ve başarısızlıklar karşısında kendine karşı sevecen olması, bu durumu insan olmanın doğal bir parçası olarak kabul etmesi ve kendini yargılamak yerine anlayışlı bir bakış açısı geliştirmesi şeklinde tanımlanmaktadır (Neff, 2003a; Raes, Pommier, Neff ve Van Gucht, 2011). Bireyin kendine gerçekçi bir gözle bakabilmesine ve kendine yönelik sağlıklı bir tutum geliştirebilmesine 
olanak sağlayan öz-şefkat; bireyin kendini olduğu gibi algılayarak kabul etmesine katkı sunmaktadır (Neff, 2003a; Neff, 2003b; Neff, Kirkpatrick ve Rude, 2007). Öz-şefkat, bireyin kendini güçlü ve zayıf yönleriyle kabul edebilmesi ve kendine sevecen bir tutum geliştirmesidir (Neff, 2003a). Öz-şefkat; öz-sevecenlik, paylaşımların bilincinde olma ve bilgece farkındalık şeklinde üç temel bileşenden oluşur. Bu bileşenler ile öz-şefkat, kişinin kendine acı veren duygu ve düşüncelerinin farkına varması ve onlarla bağlantı kurarak acılarını hafifletebilmesine, yaşanan bu acıların insan yaşamının doğal bir parçası olduğunu kendisine hatırlatmasına ve kendine karşı nazik bir yaklaşım sergilemesine olanak tanir (Neff, 2003a).

Öz-şefkat ile yapılan araştırmalarda psikolojik sağlamlık (Neff vd., 2007), psikolojik iyi oluş (Neff, Pisitsungkagarn ve Hsieh, 2008), psikolojik işlevsellik (Neff ve Vonk, 2009) ve öznel iyi oluş (Wei, Liao, Ku ve Shaffer, 2011) ile öz-şefkat arasında pozitif yönlü; depresyon ve kaygı (Bayramoğlu, 2011), alkol kullanımı (Rendon, 2006) ve travma sonrası stres bozukluğu (Thompson ve Waltz, 2008) ile öz-şefkat arasında negatif yönlü ilişki olduğu tespit edilmiştir. Bu bulgular öz-şefkatin psikolojik sorunlara karşı koruyucu bir özelliğe sahip olduğunu düşündürmektedir. Bunlara ek olarak öz-şefkatin mutluluk, iyimserlik ve bilgelikle de yakından ilişkili olduğu, kişiliğin güçlü yanlarını geliştirdiği ve işlevsel ve doyumlu bir yaşam sürmede etkin rol oynayabildiği ifade edilmektedir (Neff vd., 2007). Ergenlik döneminde, duygu durumlarının değişkenlik gösterdiği ve bu nedenle ergenlerin duygu yönetimi becerilerinin düşük olduğu ifade edilmektedir (Steinberg, 2013). Bu bağlamda duygu düzenlemede tamamlayıcı bir kavram olduğu ileri sürülen öz-şefkatin (Neff vd., 2007), ergenlik döneminde bireyin psikolojik sağlığına olumlu yönde etki edebileceği söylenebilir. Söz konusu araştırmaların yetişkinlerle gerçekleştirildiği ve ergenlerle yapılan araştırmaların ise sınırlı sayıda olduğu (Neff ve McGehee, 2010; Yıldırım, 2018) dikkate alındığında, öz-şefkat kavramının ergenler üzerinde araştırılmasının alanyazına katkı sağlayacağı düşünülebilir.

Germer (2020), travma geçirmiş pek çok kişinin, iyi hissetmeyi hak etmediğini düşündügünü, duygusal acıyı güvenli dozlarda deneyimlemekte güçlük çektiğini ve bireye acı veren duyguların, daha 
eski acıları da beraberinde getirdiğini savunmaktadır. Diğer bir deyişle olumsuz yaşantıların bireyin öz-şefkat ve duygu düzenleme becerilerini olumsuz etkilediğini öne sürmektedir. Özellikle yaşamın erken yıllarında deneyimlenen olumsuz yaşantıların kendi ve diğerleriyle uyumsuz ilişkiler geliştirme (Kendall-Tackett, 2002), kendini beğenmeme (Gilbert ve Procter, 2006), problemli madde kullanımı (Dunn, Tarter, Mezzich, Vanyukov, Kirisci ve Kirillova, 2002) ve psikopatoloji (Ravndal, Lauritzen, Frank, Jansson ve Larsson, 2001) ile ilişkili olduğu belirtilmektedir. $\mathrm{Bu}$ doğrultuda erken dönem olumsuz yaşantılara odaklanan "şema terapi yaklaşımı" nın lise öğrencilerinde öz-şefkat ve duygusal özerklik ile birlikte incelenmesinin, bir ihtiyaç olduğu söylenebilir.

Şema terapinin, bilişsel-davranış̧̧ı terapi şemsiyesi altında ortaya çıkan ve psikopatolojilere farklı bir bakış açısıyla yaklaşan yenilikçi ve bütünleyici bir terapi yaklaşımı olduğu ifade edilmektedir (Young ve Klosko, 2011). Young (1999) ve Young, Klosko ve Weishaar (2003) tarafından kişilik bozukluğu olan ve geleneksel bilişsel terapiye cevap vermeyen ya da kötüleşen danışanlara daha etkili tedavi verme çabalarından hareketle geliştirilen şema terapi; yapılandırılmış sistemli bir yaklaşıma dayanmaktadır. Şema terapi; bilişsel, davranışsal ve yaşantısal örüntüleri kırma müdahaleleri ile çok sayıda psikolojik soruna yönelik tedavi imkanı sunan bir yaklaşımdır. Şema terapi yaklaşımında; bilişsel, psikodinamik, nesne ilişkileri ve gestalt psikoterapi gibi yaklaşımların farklı yanlarının stratejik olarak bütünleştirilmesi, bu yaklaşımın özgün ve etkili bir tedavi yöntemi olmasını sağlamıştır (Farrell, Reiss ve Shaw, 2015). Şema terapi yaklaşımı; bireyin ruhsal açıdan sağlıklı ve uyumlu bir yaşam sürdürebilmesi için yaşamın erken yıllarında karşılanması gereken evrensel temel ihtiyaçların olduğunu ileri sürmektedir. Bu temel ihtiyaçlar; güvenli bağlanma, özerklik, kendiliğindenlik ve oyun, yetkinlik ve kimlik algısı, özgürlük ve gerçekçi sinurlar olarak ifade edilmektedir (Young ve Klosko, 2011). Temel ihtiyaçların karşılanmaması ya da örseleyici şekilde engellenmesi sonucunda, şema adı verilen güçlü düşünce kalıpları/inançlar oluşmaktadır. Erken yıllarda deneyimlenen olumsuz yaşantılar ve maruz kalınan kötü muamele de şemaların oluşumunda etkili olmaktadır (Young vd., 2003). Şema oluşumunda mizaç yapısının 
belirleyici bir faktör olduğu ve aynı koşul ve durumlarda, farklı mizaçların farklı şemalar oluşturduğu belirtilmektedir (Young ve Klosko, 2011). Katı, yıkıcı ve değiştirilmesi oldukça güç olan erken dönem uyumsuz şemalar, kendini yineleyici ve hayatta kalmaya yönelik örüntüler şeklinde ifade edilmektedir (Young vd., 2003). Birey için ac1 verici olsa da aynı zamanda rahatlatıcı ve tanıdık olmaları sebebiyle şemalar, bireye tutarlılık ve kontrol hissi sağlamaktadır (Young, 1999). Erken dönem uyumsuz şemalar bu yönüyle uyum sağlayıcı gibi görünse de, bireyin benlik algısı ve diğerleri ile olan ilişkilerine zarar veren hatalı, işlev bozucu ve sınırlayıcı bir yapıya sahiptir (Farrell vd., 2015).

İçerik alanlarına göre beş şema alanı ve 18 erken dönem uyumsuz şema belirlenmiştir. Güvenlik, sevgi ve ait olma gibi temel ihtiyaçların diğer insanlar tarafından karşılanmayacağına ilişkin inançlar doğrultusunda şekillenen kopukluk ve reddedilmişlik şema alanında terk edilme, kuşkuculuk/kötüye kullanma, duygusal yoksunluk, kusurluluk ve sosyal izolasyon şemaları yer almaktadır. Bağımlılık/yetersizlik, dayanıksızlık, yapışıklık/gelişmemiş benlik ve başarısızlık şemalarının yer aldığı zedelenmiş özerklik ve performans şema alanı ise bireylerin ebeveyn figürlerinden sağlıklı bir şekilde bağımsızlaşma becerileriyle ilişkilidir. Zedelenmiş sınırlar şema alanı, bireylerin içsel sınırlar koyma, diğer insanların haklarına saygı gösterme, işbirliğine açık olma ve uzun vadeli hedeflere ulaşma gibi konularda güçlük çektiği ve haklllık/büyüklenmecilik ve yetersiz özdenetim şemalarının yer aldığı şema alanıdır. Bir diğer şema alanı, sevgi ve kabul görme ve olası olumsuz tepkilerden kaçınma adına diğer insanların ihtiyaç, istek ve duygularına aşırı odaklanma ile beliren ve boyuneğicilik, onay arayıcılık ve kendini feda şemalarını kapsayan diğerleri yönelimlilik şema alanıdır. Aşırı tetikte olma/bastırılmışlık şema alanı ise bireylerin kendiliğinden duygu, dürtü ve tercihlerini bastırmasıyla karakterize olmakta ve duyguları bastırma, yüksek standartlar, karamsarlık ve cezalandırıcılık şemalarını kapsamaktadır (Farrell vd., 2015; Young vd., 2003).

\section{Erken Dönem Uyumsuz Şemaların Aracı Rolü}

Gelişimsel psikopatolojiyi tetikleyecek çok fazla etkenin bulunması nedeniyle ergenlik dönemindeki bireylerin risk altında ve savunmasız 
olduğu düşünülmektedir (Wenar ve Kerig, 2000). Bu riskin lise döneminde arttığı ve lise öğrencilerinde tehlikeli sporlara yönelme (Diehm ve Armatas, 2004), alkol ve madde kullanımı (Cicognani ve Zani, 2011), intihar (Eskin, Ertekin, Harlak, ve Dereboy, 2008) ve korunmasız cinsel ilişki (Donohew, Zimmerman, Cupp, Novak, Colon vd., 2000) gibi çok sayıda sorunun ortaya çıtığı görülmektedir. Kendini suçlama ve küçümsemenin arttığı bu dönemde, öz-değerlilik, özerklik ve kişisel kimlik etrafındaki sorunlar giderek daha merkezde yer almaya başlamaktadır (Loose vd., 2018). Öz-güven (Beyers ve Goosens, 1999), bilişsel esneklik ve duygu düzenleme (Öztürk, 2019) ve psikolojik sağlamlık (Akman, Abaslı ve Polat, 2018) gibi kavramlarla pozitif ilişkisi olan duygusal özerkliğin, lise öğrencilerinin bu sorunlarla başa çıkabilmesine önemli katkılar sunacağı düşünülebilir. Öte yandan lise öğrencilerinin duygusal özerklik yolunda ilerleyebilmesi için öz-şefkat gibi dengeli ve tutarlı bir başa çıkma yöntemine ihtiyaç duyacağ 1 söylenebilir. Bir tür duygu düzenleme tekniği olarak kabul edilen özşefkat (Diedrich, Grant, Hofmann, Hiller ve Berking, 2014), duygusal sağlık ve duygusal zeka ile pozitif ilişkilidir (Neff, 2003a). Bu doğrultuda, öz-şefkatin duygusal özerklik gelişiminde önemli bir belirleyici olabileceği düşünülebilir. Ancak, öz-şefkatin, erken çocukluk deneyimleriyle yakından ilişkili olduğu ve yaşamın erken dönemindeki koşullar sonucunda oluşan erken dönem uyumsuz şemaların, özşefkatin gücünü tam olarak kullanma yeteneğini olumsuz etkilediği belirtilmektedir (Germer, 2020). Ayrıca, düşük öz-şefkat düzeyi ve erken dönem uyumsuz şemaların gelişimi, olumsuz çocukluk deneyimleri ve maruz kalınan kötü muamele ile ilişkilendirilmekte (Vettese, Dyer, Li ve Wekerle, 2011; Young, 1999) ve erken dönem uyumsuz şemaların, duygusal tepkileri şekillendirdiği belirtilmektedir (Masomi, Hejazi ve Sobhi, 2014). Kendinden utanan ve sürekli kendini eleştiren bireylere yönelik gerçekleştirilen öz-şefkatli zihin eğitimi programı sonunda, kendilerini yatıştırma yoluyla olumlu duygular oluşturmakta güçlük çeken bireylerin muhtemelen erken yaşlarda yeterince rahatlatılmamış ve güvende hissetmemiş oldukları varsayımı öne çıkmıştır (Gilbert, 2009). Diğer bir ifadeyle, erken dönem yaşantılarında sevilme ve güvende hissetme gibi temel ihtiyaçları karşılanmamış bireylerin, özşefkati etkili şekilde kullanamadıkları anlaşılmaktadır. Bu durumda öz- 
şefkati etkili bir şekilde kullanabilmek için şemaların nasıl ortaya çıktığını bilmek, onları görmek ve hissetmek gerekmektedir. Böylece, birey hangi şemaların kendisini ilgilendirdiğini anlayabilmesi ve söz konusu şemaların da birey üzerindeki kontrolünün kaybolması mümkün olacaktır (Germer, 2020). Bu yönüyle ergenlerde öz-şefkat ve duygusal özerklik arasındaki ilişkide erken dönem uyumsuz şemaların etkisinin belirlenmesinin önemli olduğu düşünülmektedir.

Alanyazında, erken dönem uyumsuz şemalar ile öz-şefkatin birlikte ele alındığ1 araştırmalarda (Fırıncı, 2019; Güzey, 2020; Thimm, 2017; Yakın, 2015; Yakın, Gençöz, Steenbergen ve Arntz, 2019), erken dönem uyumsuz şemalar ile farklı değişkenler arasındaki ilişkilerde öz-şefkatin aracılık rolünün incelendiği görülmektedir. Yetişkin bireylerle gerçekleştirilen söz konusu araştırmalarda, öz-şefkatin, erken dönem uyumsuz şemaların diğer değişkenler üzerindeki etkisini azalttığına vurgu yapılmaktadır. Öte yandan erken dönem uyumsuz şemaların aracılık etkisinin incelendiği araştırmaların sınırlı sayıda olduğu ve bu araştırmalarda da öz-şefkat ve duygusal özerklik değişkenlerinin yer almadığı göze çarpmaktadır (Balsamo, Carlucci, Sergi, Murdock ve Saggino, 2015; Bosmans, Braet ve Vlierberghe, 2010; Carlucci, D'Ambrosio, Innamorati, Saggino ve Balsamo, 2018; Roelofs, Lee, Ruijten ve Lobbestael, 2011; Roelofs, Onckels ve Muris, 2013). Ayrica, alanyazında ergen bireylerde erken dönem uyumsuz şemaların incelendiği araştırmaların sınırlı sayıda olduğu (Gökçe, Önal Sönmez, Yusufoğlu, Yulaf ve Adak, 2017; Koçak, 2020; Richardson, 2005; Sarıtaş ve Gençöz, 2011) ve bu nedenle erken dönem uyumsuz şemaların ergenler üzerindeki etkilerinin araştırılmasının alanyazına katkı sağlayacağı söylenebilir. Bu doğrultuda lise öğrencilerinde öz-şefkat ile duygusal özerklik arasındaki ilişkide erken dönem uyumsuz şemaların aracılık rolünün incelenmesi bu araştırmanın amacını oluşturmaktadır.

Alanyazın incelendiğinde, şema alanları dikkate alınarak aracılık modellerinin kurulduğu ve araştırmaların bu doğrultuda gerçekleştirildiği görülmektedir (Balsamo, vd., 2015; Fırıncı, 2019; Roelofs vd., 2011; Roelofs vd., 2013; Thimm, 2017; Yakın, 2015; Yakın vd., 2019). Bu nedenle, güncel araştırmada da alanyazında yapılan araştırmalara benzer şekilde modeller oluşturulmuştur. Bu doğrultuda, öz-şefkat araştırmanın bağımsız değişkeni, erken dönem uyumsuz şema 
alanları araştırmanın aracı değişkeni ve duygusal özerklik ise araştırmanın bağımlı değişkeni olarak belirlenmiştir. Test edilecek aracı modellere ilişkin bilgiler Tablo 1'de gösterilmiştir.

Tablo 1. Test Edilecek Modeller

\begin{tabular}{llll}
\hline & $\begin{array}{c}\text { Bağımsız } \\
\text { Değişken }\end{array}$ & Aracı Değişken & Bağımlı Değişken \\
\hline Aracı Model 1 & Öz-şefkat & Kopukluk-Reddedilmişlik & Duygusal Özerklik \\
Aracı Model 2 & Öz-şefkat & Zedelenmiş Özerklik ve Performans & Duygusal Özerklik \\
Aracı Model 3 & Öz-şefkat & Zedelenmiş Sınırlar & Duygusal Özerklik \\
Aracı Model 4 & Öz-şefkat & Diğerleri Yönelimlilik & Duygusal Özerklik \\
Aracı Model 5 & Öz-şefkat & Aşırı Tetikte Olma/Bastırılmışlı & Duygusal Özerklik \\
\hline
\end{tabular}

\section{Yöntem}

$\mathrm{Bu}$ araştırma; öz-şefkat, duygusal özerklik ve erken dönem uyumsuz şemalar arasındaki ilişkiyi incelemek amacıyla düzenlenmiş ilişkisel bir çalışmadır. İlişkilerin derinlemesine incelendiği bu araştırmalarda, iki ya da daha çok değişken arasındaki ilişkileri betimleme, değişimin varlığ veya derecesini belirleme amaçlanır (Karasar, 2014).

\section{Örneklem}

Araştırma sürecine, araştırma için gerekli izinlerin alınmasıyla başlanmıştır. Öncelikle araştırmada kullanılacak ölçme araçlarını geliştiren ve Türk kültürüne uyarlayan yazarlarla elektronik posta yoluyla iletişime geçilmiş ve yazarlardan ölçek kullanım izni alınmıştır. Daha sonra, Sakarya Üniversitesi Rektörlüğü Etik Kurulu'ndan anket kullanım izni (61923333/050.99/) alınarak veri toplama süreci başlatılmış ve veriler araştırmacı tarafından yüz yüze uygulama ile toplanmıştır. Araştırmada uygun örnekleme yöntemi kullanılmıştır. Ölçme araçlarının nasıl cevaplanacağını anlatan yönergeler, araştırmanın amacı ve içeriği gibi bilgiler ölçeklerin üzerine yazılmıştır. Uygulamaların başlangıcında araştırmaya katılımın gönüllük esasına dayandığı ve bu çalışmadan elde edilen sonuçların bilimsel bir araştırmada kullanılacağı öğrencilere ifade edilmiştir. Bilgilendirmeden sonra gönüllü öğrencilere ölçme araçları uygulanmıştır. Ölçekler sınıflarda gruplar halinde uygulanmış ve her bir 
uygulama yaklaşı 30 dakikada tamamlanmıştır. Uygulanan ölçek sonuçlarının araştırmacıdan alınabileceği belirtilerek uygulama sonlandırılmıştır. Katılımcılar, 2019-2020 eğitim öğretim yılında, Türkiye'nin Kocaeli ilindeki orta öğretim kurumlarında öğrenim görmekte olan \% 53.2 (296) kadın ve \% 46.8 (260) erkek olmak üzere toplam 556 ergen bireydir. Öğrencilerin yaş aralığı, 14 ile 16, yaş ortalaması ise 15.2'dir. Öğrencilerden 28.6 (159)'s1 9. sinıf ve \% 71.4 (397)'ü 10. sınıfta yer almaktadır. Öğrencilerin \% 4.1 (23)'i Fen Lisesinde, \% 5.0 (28)'1 Sosyal Bilimler Lisesinde, \% 43.3 (241)'ü Anadolu Lisesinde, \% 5.0 (28)'1 Mesleki ve Teknik Anadolu Lisesinde ve \% 42.4 (236)'ü Anadolu İmam Hatip Lisesinde öğrenim görmektedir.

\section{Veri Toplama Araçları}

Ergenler için Duygusal Özerklik Ölçeği: Steinberg ve Silverberg (1986) tarafından geliştirilen ölçek Deniz vd. (2013) tarafından Türk kültürüne uyarlanmıştır. 4'lü Likert tipi bir ölçme aracı olan ölçeğin özgün formu 20 soru ve "Anne babayı birey olarak görme, idealleştirme, bağımsızlaşma ve bireyleşme" şeklinde 4 alt boyuttan oluşmaktadır. Ölçekten alınan yüksek puan, duygusal özerklik düzeyinin yüksek olduğunu göstermektedir. Türk ergen örnekleminde düşük yük değerlerine sahip olan anne babayı birey olarak görme alt boyutu ölçekten çıkarılmış ve ölçek 14 soru ve 3 alt boyut ile analiz edilmiştir. Doğrulayıcı faktör analizi (DFA) sonuçlarına bakıldığında ölçeğin üç boyutlu yapısının doğrulandığı gözlenmiştir (RMSEA $=.068, \mathrm{RMR}=.062$, $\mathrm{GFI}=.93, \mathrm{CFI}=.90, \mathrm{NNFI}=.91, \mathrm{AGFI}=.90$ ). Ölçeğin iç tutarlılık düzeyi incelendiğinde Cronbach Alpha katsayısının .79 olduğu tespit edilmiştir. $\mathrm{Bu}$ araştırmada ise ölçeğin Cronbach Alpha katsayısı .80 olarak hesaplanmıştır.

Ergenler için Öz-Şefkat Ölçeği: Raes vd. (2011) tarafından geliştirilen ölçek Yıldırım ve Sarı (2018) tarafından Türk kültürüne uyarlanmıştır. Toplamda 12 soru ve iki alt boyuttan oluşan ölçek 5'li Likert tipi bir ölçme aracıdır. Ölçekten alınan yüksek puan, öz-şefkat düzeyinin yüksek olduğunu göstermektedir. Açımlayıcı faktör analizi (AFA) sonucunda faktör yükü .30 'un altında kalan 10. madde ölçekten çıkarılmıştır. DFA 
sonuçlarının ise mükemmel uyum verdiği belirlenmiştir (RMSEA=0.06, RMSR= 0.095, GFI= 0.96, NFI= 0.91, CFI= 0.95, NNFI= 0.94). Ölçeğin iç tutarlılık düzeyi incelendiğinde Cronbach Alpha katsayısının .75 olduğu; test tekrar test güvenirliği puanının ise .84 olduğu tespit edilmiştir. $\mathrm{Bu}$ araştırmada ise ölçeğin Cronbach Alpha katsayısı .76 olarak hesaplanmıştır. Son haliyle ölçeğin 11 madde ve tek boyuttan oluştuğu ifade edilmiştir (Yıldırım ve Sarı, 2018).

\section{0-16 Yas, Çocuk ve Ergenler için Erken Dönem Uyumsuz Şema Ölçekler}

Takımı: Güner (2013) tarafından geliştirilen ölçek, toplamda 97 maddeden oluşan 5'li Likert tipi bir ölçme aracıdır. Ölçekten alınan yüksek puan, ilgili şema düzeyinin yüksek olduğunu göstermektedir. Ölçekte 5 şema alanı, 15 erken dönem uyumsuz şema yer almaktadır. Şema alanları; kopukluk-reddedilmişlik (RMSEA=.05, GFI=.92, AGFI=.91, $\mathrm{CFI}=.90$, NFI=.84), zedelenmiş özerklik ve performans (RMSEA=.05, GFI=.94 AGFI=.93, CFI=.91, NFI=.87), zedelenmiş sınırlar (RMSEA $=.06$, $\mathrm{GFI}=.92$, AGFI $=.90, \mathrm{CFI}=.86, \mathrm{NFI}=.83$ ), diğerleri yönelimlilik (RMSEA=.04, $\mathrm{GFI}=.96, \mathrm{AGFI}=.95, \mathrm{CFI}=.92, \mathrm{NFI}=.90 \mathrm{CFI}=.91, \mathrm{NFI}=.87)$ ve aşırı tetikte olma/bastırılmışlık (RMSEA=.06, GFI $=.90$, AGFI=.94, CFI $=.93, \mathrm{NFI}=.91$ ) şeklinde belirlenmiştir. Faktör analizleri sonucunda, sosyal izolasyon, kendini feda, duygular bastırma ve yüksek standartlar şemalarının ölçeğin ergen formunda yer almadığı, ergen formuna kendini onaylamama adıyla yeni bir şema eklendiği ifade edilmiştir (Güner, 2013). Erken dönem uyumsuz şemalar sırasıyla; kusurluluk, kuşkuculuk/kötüye kullanılma, duygusal yoksunluk, terk edilme, başarısızlık, bağımlılık, yapışıklık/gelişmemiş benlik, dayanıksızlık, haklılık, yetersiz özdenetim, boyun eğicilik, kendini onaylamama, onay arayıcılık, karamsarlık ve cezalandırıcılık şeklinde belirlenmiştir (Güner, 2013). Ölçeğin iç tutarlılık düzeyi incelendiğinde, Cronbach Alpha katsayılarının sırasıyla; .89, .85, $.86, .78, .82$ ve test tekrar test güvenirliği puanlarının ise sırasıyla; $.99, .97$, $.98, .97, .97$ olduğu tespit edilmiştir. Bu araştırmada, katılımcılar ölçeğin 97 maddelik özgün formunu cevaplamış ve ölçeğin Cronbach Alpha katsayıları sırasıyla; .91, .87, .86, .85 ve .86 olarak hesaplanmıştır. 


\section{Veri Analizi}

Öncelikle dağılım, normallik açısından incelenmiş ve verilerin normal dağılıma uygunluğunu belirlemek için çarpıklık ve basıklık değerleri gözden geçirilmiştir. Değişkenlerin çarpıklık değerlerinin -.02 ile .93 aralığında; basıklık değerlerinin ise .06 ile .91 aralığında olması ve değerlerin -1 ile +1 arasında yer alması, verilerin normallik açısından kabul edilebilir düzeyde olduğunu göstermektedir (Büyüköztürk, 2019; Şencan, 2005). Araştırmada öz-şefkat ile erken dönem uyumsuz şemalar arasındaki korelasyonlar -.52 ile -.18 arasında değişmekte ve 15 ilişkinin tamamının anlamlı ( $p<.05)$ olduğu görülmektedir. Ayrıca öz-şefkat ile duygusal özerklik arasındaki ilişkinin de anlamlı olduğu $(r=.24, p<.05)$ tespit edilmiştir. Son olarak, erken dönem uyumsuz şemalar ile duygusal özerklik arasındaki ilişkiler -.04 ile - -.36 arasında değişmekte ve 4 ilişkinin (bağımlılık, dayanıksızlık, boyun eğicilik ve onay arayıcılık) anlamlı olmadığı $(p>$.05) görülmektedir. Elde edilen korelasyon değerleri, mevcut değişkenler ile bir aracılık modelinin kurulabileceğini göstermiştir. Veri setinin normallik sayıltılarını karşılamasının ardından regresyon analizi sayıltıları gözden geçirilmiştir. Elde edilen bulgularda tüm değişkenlerin Tolerance değerlerinin .10'dan büyük, VIF değerlerinin 10'dan düşük olması, veri setinin normalliğini ve veri setinde çoklu bağlantı problemi olmadığını göstermektedir (Pallant, 2007).

Araştırmada lise öğrencilerinin duygusal özerkliklerini yordayan faktörlerin aracılık modeli, Hayes (2013) tarafından geliştirilen ve SPSS yazılımında eklenti şeklinde çalışan Process makro ile incelenmiştir. Regresyon analizinde 5000 yeniden örnekleme (resample) yöntemi kullanilan bu ek yazılımda, bir araştırma modelinde yer alan tüm değişkenlerin yol katsayıları, standart hataları, $t$ ve $p$ değerleri ve bootstrap güven aralıkları hesaplanabilmektedir (Hayes, 2013). Bu çalışmada aracı değişken olan erken dönem uyumsuz şemaların dolaylı etkileri bootstrap tekniği kullanılarak yorumlanmıştır. Arac1 değişkenlerin \% 95 güven aralığında bootstrap alt (BootLLCI) ve üst (BootULCI) değerleri arasında sıfır bulunmaması, diğer bir ifadeyle iki değerin de sıfırın altında ya da üstünde olması durumunda aracılığın anlamlı olduğu kabul edilmiştir (Hayes, 2013; Zhao, Lynch ve Chen, 
2010). Aracilık etkisinin tam standardize etki büyüklügü $\left(K^{2}\right)$, Preacher ve Kelley (2011)'nin önerdiği “.01'e yakın ise düşük etki, .09'a yakın ise orta etki ve .25'e yakın ise yüksek etki" değerleri dikkate alınarak yorumlanmıştır.

Process makro yazılımda Model 4 kullanılmıştır. Model 4'te, basit ve çok değişkenli aracılık analizleri gerçekleştirilebilmekte ve modele 1 ile 10 arasında aracı değişken atanabilmektedir. Bu doğrultuda, öz-şefkat, araştırmanın bağımsız değişkenini, erken dönem uyumsuz şema alanları aracı değişkenlerini, duygusal özerklik ise bağımlı değişkenini oluşturmaktadır. Model 4'e ilişkin diyagrama Şekil 1'de yer verilmiştir.

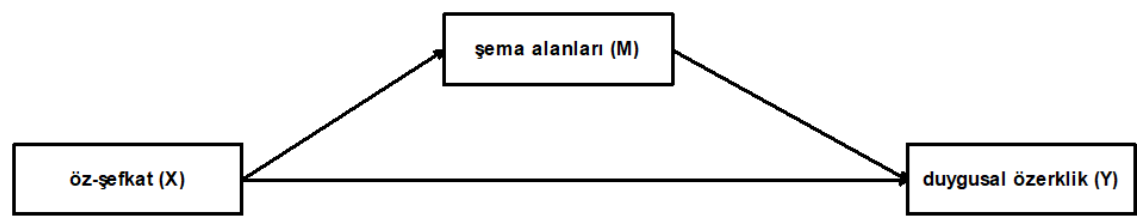

Şekil 1. Model 4'e İlişkin Diyagram

\section{Bulgular}

Lise öğrencilerinde öz-şefkat ile duygusal özerklik arasındaki ilişkide erken dönem uyumsuz şemaların aracı rolü incelenmiştir. Araştırmada, öz-şefkatin, erken dönem uyumsuz şemalar aracıllğı ile duygusal özerkliği yordayıp yordamadığı Hayes (2013) tarafından geliştirilen Process makro ile sınanmıştır. Bu doğrultuda beş şema alanı dikkate alınarak, sırası ile beş model incelenmiş ve şema alanlarında yer alan erken dönem uyumsuz şemalar modellere aracı değişken olarak atanmıştır. Aracı modeller Tablo 2, 3, 4, 5, 6 ve Şekil 2, 3, 4, 5 ve 6'da gösterilmektedir.

\section{Model 1 - Kopukluk-Reddedilmişlik Şema Alanının Aracı Rolü}

Tablo 2'de, öz-şefkat (X) ile duygusal özerklik (Y) arasında aracı değişken olan kopukluk-reddedilmişlik şema alanının (kusurluluk-M1, kuşkuculuk-M2, duygusal yoksunluk-M3 ve terk edilme-M4) etkisini gösteren regresyon analizi sonuçlarına yer verilmiştir. Buna göre, öz- 
şefkatin, kusurluluk $(\beta=-.19 ; t=-10.71 ; p<.05)$, kuşkuculuk $(\beta=-.37 ; t=-$ $12.67 ; p<.05)$ ve terk edilme $(\beta=-.18 ; t=-10.33 ; p<.05)$, şemalarını negatif ve duygusal özerkliği pozitif yordadığı $(\beta=.11 ; t=2.49 ; p<.05)$; duygusal yoksunluk şemasının ise duygusal özerkliği negatif yordadığ $1(\beta=-.34 ; t=$ -6.75; $p<.05)$ belirlenmiştir. Öte yandan kusurluluk $(\beta=.15 ; t=1.49 ; p>$ $.05)$, kuşkuculuk $(\beta=.01 ; \mathrm{t}=.15 ; p>.05)$ ve terk edilme $(\beta=.25 ; t=1.39 ; p>$ .05) şemalarının duygusal özerkliği yordamadığı tespit edilmiştir. Bu bağlamda aracı değişkenlerin \%95 güven aralığında dolaylı etkileri incelendiğinde, duygusal yoksunluk şeması için BootLLCIduy= .12; BootULCIduy $=.23$ olarak hesaplanmıştır. \%95 güven aralığındaki bootstrap alt (BootLLCI) ve üst (BootULCI) değerleri arasında sıfır bulunmadığından, duygusal yoksunluk şemasının bu modelde anlamlı bir aracılık rolünün olduğu tespit edilmiştir. Aracilık etkisinin tam standardize etki büyüklüğü değeri olan $K^{2}$ duy $=.18$, aracllık etkisinin yüksek değere yakın bir etkiye sahip olduğunu göstermektedir. Aracı Model 1'in grafiksel gösterimine Şekil 2'de yer verilmiştir.

Tablo 2. Öz-Şefkat ile Duygusal Özerklik Arasındaki İlişkide KopuklukReddedilmişlik Şema Alanımın Aracı Rolü

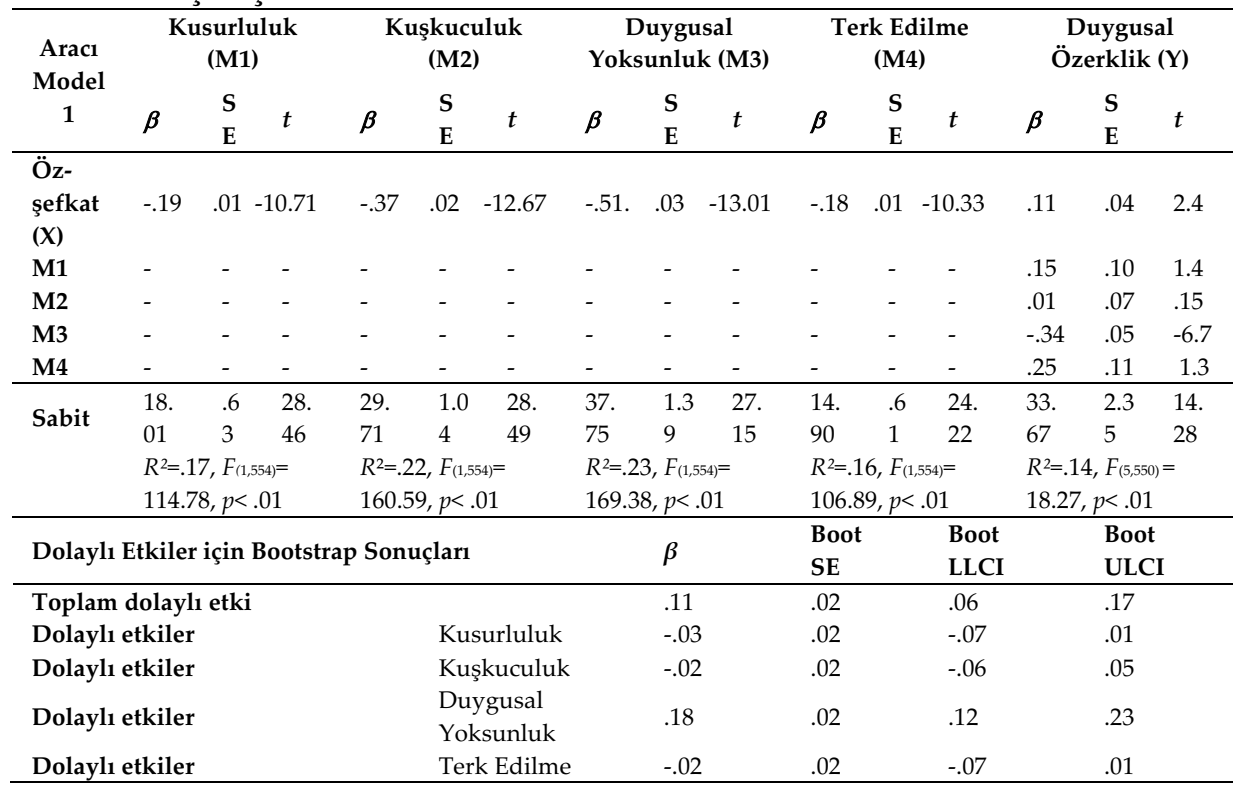




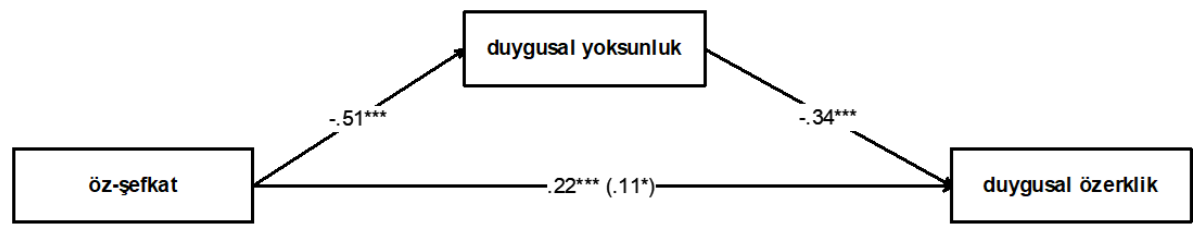

${ }^{*} \mathrm{p}<.05,{ }^{* *} \mathrm{p}<.01,{ }^{* * *} \mathrm{p}<.001$

Şekil 2. Öz-Şefkat ile Duygusal Özerklik Arasındaki İlişkide KopuklukReddedilmişlik Şema Alanının Aracı Rolü (Aracı Model 1)

\section{Model 2 - Zedelenmiş Özerklik-Performans Şema Alanının Aracı Rolü}

Korelasyon analizinde zedelenmiş özerklik ve performans şema alanında yer alan bağımlılık ve dayanıksızlık şemaları ile duygusal özerklik arasında anlamlı ilişki olmaması nedeniyle, söz konusu değişkenler öz-şefkat ile duygusal özerklik arasındaki ilişkide zedelenmiş özerklik ve performans şema alanının aracı rolünün sınandığı modele dahil edilmemiştir.

Tablo 3. Öz-Şefkat ile Duygusal Özerklik Arasındaki İlişkide Zedelenmiş Özerklik ve Performans Şema Alanımın Aracı Rolï

\begin{tabular}{|c|c|c|c|c|c|c|c|c|c|}
\hline \multirow{2}{*}{$\begin{array}{l}\text { Aracı } \\
\text { Model } 2\end{array}$} & \multicolumn{3}{|c|}{$\begin{array}{l}\text { Başarısizlık } \\
\text { (M1) }\end{array}$} & \multicolumn{3}{|c|}{$\begin{array}{l}\text { Yap1şıklık } \\
\text { (M2) }\end{array}$} & \multicolumn{3}{|c|}{$\begin{array}{l}\text { Duygusal Özerklik } \\
\text { (Y) }\end{array}$} \\
\hline & $\beta$ & SE & $t$ & $\beta$ & SE & $t$ & $\beta$ & SE & $t$ \\
\hline $\begin{array}{l}\text { Özşefkat } \\
\text { (X) }\end{array}$ & -.40 & .03 & -13.43 & -.07 & .01 & -4.30 & .20 & .04 & 4.90 \\
\hline M1 & - & - & - & - & - & - & -.19 & .05 & -3.72 \\
\hline M2 & - & - & - & - & - & - & .82 & .09 & 8.57 \\
\hline \multirow[t]{2}{*}{ Sabit } & 31.30 & 1.06 & 29.47 & 10.34 & .58 & 17.78 & 23.61 & 2.16 & 10.91 \\
\hline & \multicolumn{3}{|c|}{$\begin{array}{l}R^{2}=.24, F_{(1,554)}=180.53 \\
p<.01\end{array}$} & \multicolumn{3}{|c|}{$\begin{array}{l}R^{2}=.03, F_{(1,554)}=18.55 \\
p<.01\end{array}$} & \multicolumn{3}{|c|}{$\begin{array}{l}R^{2}=.17, \mathrm{~F}_{(3,552)}=38.85, \\
p<.01\end{array}$} \\
\hline \multirow{2}{*}{\multicolumn{4}{|c|}{$\begin{array}{l}\text { Dolaylı Etkiler için Bootstrap } \\
\text { Sonuçları }\end{array}$}} & & & \multirow[t]{2}{*}{$\beta$} & Boot & Boot & Boot \\
\hline & & & & & & & SE & LLCI & ULCI \\
\hline \multicolumn{4}{|c|}{ Toplam Dolaylı Etki } & \multirow{2}{*}{\multicolumn{2}{|c|}{$\begin{array}{l}\text { Başarısızlık } \\
\text { Yapısıklık }\end{array}$}} & $\begin{array}{l}.02 \\
.07\end{array}$ & $\begin{array}{l}.02 \\
.02\end{array}$ & $\begin{array}{l}-.03 \\
.03\end{array}$ & $\begin{array}{l}.07 \\
.12\end{array}$ \\
\hline \multicolumn{4}{|c|}{$\begin{array}{l}\text { Dolaylı Etkiler } \\
\text { Dolaylı Etkiler }\end{array}$} & & & -.05 & .01 & -.09 & -.03 \\
\hline
\end{tabular}

Tablo 3'te, öz-şefkat (X) ile duygusal özerklik (Y) arasında aracı değişken olan zedelenmiş özerklik ve performans şema alanının (başarısızlık-M1 ve yapışıklık-M2) etkisini gösteren regresyon analizi sonuçlarına yer verilmiştir. Buna göre, öz-şefkatin, başarısızlık şemasını 
$(\beta=-.40 ; t=-13.43 ; p<.05)$ ve yapışıklık şemasını negatif yordadığı $(\beta=-.07 ;$ $t=-4.30 ; p<.05)$; duygusal özerkliği ise pozitif yordadığ $1(\beta=.20 ; t=4.90$; $p<.05)$ belirlenmiştir. Öte yandan duygusal özerkliği, başarısızlık şemasının negatif $(\beta=-.19 ; t=-3.72 ; p<.05)$, yapışıklık şemasının ise pozitif yordadığ $1(\beta=.82 ; t=8.57 ; \beta<.05)$ tespit edilmiştir. Bu bağlamda arac1 değişkenlerin \% 95 güven aralı̆̆ında dolaylı etkileri incelendiğinde, başarısızlık şeması için BootLLCI baş $=.03$; BootULCI baş= 12 ve yapışıklık şeması için BootLLCI $I_{y a p}=-.09$; BootULCI $I_{y a p}=-.03$; olarak hesaplanmıştır. \% 95 güven aralığındaki bootstrap alt (BootLLCI) ve üst (BootULCI) değerleri arasında sıfır bulunmadığından, başarısızlık ve yapışıklık şemalarının bu modelde anlamlı bir aracılık rolünün olduğu tespit edilmiştir. Aracılık etkisinin tam standardize etki büyüklüğü değerleri olan $K^{2}$ bas $=.07$ ve $K^{2}$ yap $=-.05$, aracılık etkisinin orta değere yakın bir etkiye sahip olduğunu göstermektedir. Aracı Model 2'nin grafiksel gösterimine Şekil 3'te yer verilmiştir.

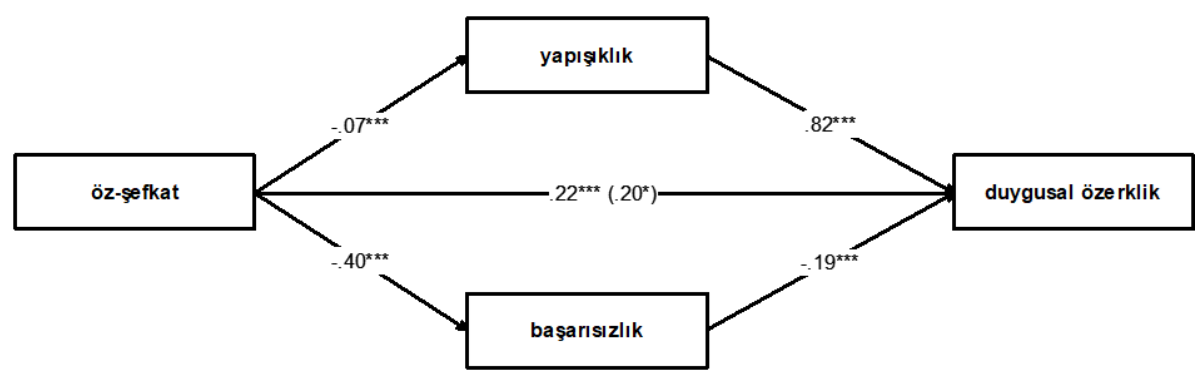

${ }^{*} \mathrm{p}<.05,{ }^{* *} \mathrm{p}<.01,{ }^{* * *} \mathrm{p}<.001$

Şekil 3. Öz-Şefkat ile Duygusal Özerklik Arasındaki İlişkide Zedeleniş Özerklik ve Performans Şema Alanının Aracı Rolü (Aracı Model 2)

\section{Model 3 - Zedelenmiş Sınırlar Şema Alanının Aracı Rolü}

Tablo 4' te, öz-şefkat (X) ile duygusal özerklik (Y) arasında aracı değişken olan zedelenmişs sınırlar şema alanının (haklılık-M1 ve yetersiz özdenetimM2) etkisini gösteren regresyon analizi sonuçlarına yer verilmiştir. Buna göre, öz-şefkatin, haklılık şemasını $(\beta=-.52 ; t=-9.58 ; p<.05)$ ve yetersiz öz denetim şemasını negatif yordadığ $1(\beta=-.15 ; t=-6.13 ; p<.05)$; duygusal özerkliği ise pozitif yordadığ $1(\beta=.13 ; t=3.40 ; \beta<.05)$ belirlenmiştir. Öte 
yandan duygusal özerkliği, yetersiz özdenetim şemasının negatif yordadığı $(\beta=-.46 ; t=-6.35 ; \beta<.05)$, haklılık şemasının ise yordamadığ1 $(\beta=-.03 ; t=-1.19 ; \quad p>.05)$ tespit edilmiştir. Bu bağlamda arac1 değişkenlerin \% 95 güven aralı̆̆ında dolaylı etkileri incelendiğinde, yetersiz özdenetim şeması için BootLLCIyet $=.04$; BootULCIyet $=.10$ olarak hesaplanmıştır. \% 95 güven aralığındaki bootstrap alt (BootLLCI) ve üst (BootULCI) değerleri arasında sıfır bulunmadığından yetersiz özdenetim şemasının bu modelde anlamlı bir aracılık rolünün olduğu tespit edilmiştir. Aracılık etkisinin tam standardize etki büyüklüğü değeri olan $K^{2}{ }_{\text {yet }}=.07$, aracılık etkisinin orta değere yakın bir etkiye sahip olduğunu göstermektedir. Aracı Model 3'ün grafiksel gösterimine Şekil 4'te verilmiştir.

Tablo 4. Öz-Şefkat ile Duygusal Özerklik Arasındaki İlişkide Zedelenmiş Sınırlar Şema Alanının Aracı Rolï

\begin{tabular}{|c|c|c|c|c|c|c|c|c|c|}
\hline \multirow{2}{*}{$\begin{array}{l}\text { Arac1 } \\
\text { Model } 3\end{array}$} & \multicolumn{3}{|c|}{$\begin{array}{l}\text { Haklılık } \\
\text { (M1) }\end{array}$} & \multicolumn{3}{|c|}{$\begin{array}{l}\text { Yetersiz Özdenetim } \\
\text { (M2) }\end{array}$} & \multicolumn{3}{|c|}{$\begin{array}{l}\text { Duygusal Özerklik } \\
\text { (Y) }\end{array}$} \\
\hline & $\beta$ & SE & $t$ & $\beta$ & SE & $t$ & $\beta$ & SE & $t$ \\
\hline Özşefkat (X) & -.52 & .05 & -9.58 & -.15 & .02 & -6.13 & .13 & .04 & 3.40 \\
\hline M1 & - & - & - & - & - & - & -.03 & .03 & -1.19 \\
\hline M2 & - & - & - & - & - & - & -.46 & .07 & -6.35 \\
\hline \multirow[t]{2}{*}{ Sabit } & 54.30 & 1.92 & 28.32 & 19.86 & .88 & 22.53 & 37.30 & 2.09 & 17.79 \\
\hline & \multicolumn{3}{|c|}{$\begin{array}{l}R^{2}=.14, F(1,554)=91.88, \\
p<.01\end{array}$} & \multicolumn{3}{|c|}{$\begin{array}{l}R^{2}=.06, F_{(1,554)}=37.66 \\
p<.01\end{array}$} & \multicolumn{3}{|c|}{$\begin{array}{l}R^{2}=.15, F_{(3,552)}=34.82, \\
p<.01\end{array}$} \\
\hline \multicolumn{4}{|c|}{$\begin{array}{l}\text { Dolaylı Etkiler için Bootstrap } \\
\text { Sonuçları }\end{array}$} & & & $\beta$ & Boot SE & BootLLCI & BootULCI \\
\hline \multicolumn{4}{|c|}{ Toplam Dolaylı Etki } & & & .09 & .01 & .05 & .13 \\
\hline \multicolumn{4}{|c|}{ Dolaylı Etkiler } & \multicolumn{2}{|c|}{ Haklılık } & .02 & .01 & -.01 & .05 \\
\hline \multicolumn{4}{|c|}{ Dolaylı Etkiler } & \multicolumn{2}{|c|}{$\begin{array}{l}\text { Yetersiz } \\
\text { Özdenetim }\end{array}$} & .07 & .01 & .04 & .10 \\
\hline
\end{tabular}

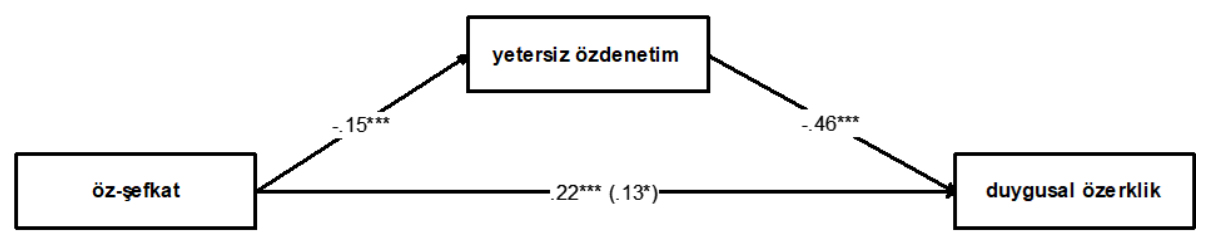

${ }^{*} \mathrm{p}<.05,{ }^{* *} \mathrm{p}<.01,{ }^{* * *} \mathrm{p}<.001$

Şekil 4. Öz-Şefkat ile Duygusal Özerklik Arasındaki İlişkide Zedeleniş Sınırlar Şema Alanının Aracı Rolü (Aracı Model 3) 


\section{Model 4 - Diğerleri Yönelimlilik Şema Alanının Aracı Rolü}

Korelasyon analizinde diğerleri yönelimlilik şema alanında yer alan boyun eğicilik ve onay arayıcıllk şemaları ile duygusal özerklik arasında anlamlı ilişki olmaması nedeniyle, söz konusu değişkenler öz-şefkat ile duygusal özerklik arasındaki ilişkide diğerleri yönelimlilik şema alanının aracı rolünün sınandığı modele dahil edilmemiştir.

Tablo 5. Öz-Şefkat ile Duygusal Özerklik Arasındaki İlişkide Diğerleri Yönelimlilik Şema Alanının Aracı Rolü

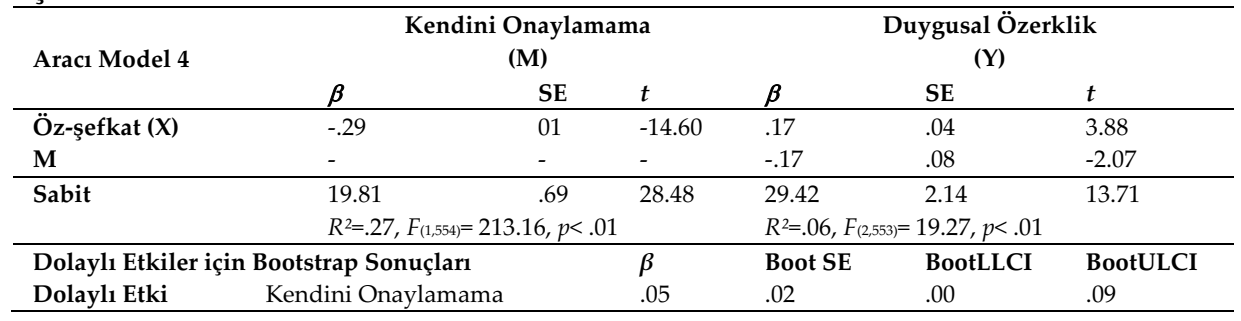

Tablo 5'te, öz-şefkat (X) ile duygusal özerklik (Y) arasında aracı değişken olan diğerleri yönelimlilik şema alanının (kendini onaylamamaM) etkisini gösteren regresyon analizi sonuçlarına yer verilmiştir. Buna göre, öz-şefkatin, kendini onaylamama şemasını negatif $(\beta=-.29 ; t=-$ 14.60; $p<.05)$; duygusal özerkliği ise pozitif yordadığı $(\beta=.17 ; t=3.88 ; p<$ $.05)$ belirlenmiştir. Öte yandan duygusal özerkliği, kendini onaylamama şemasının negatif yordadığı $(\beta=-.17 ; t=-2.07 ; p<.05)$ tespit edilmiştir. $\mathrm{Bu}$ bağlamda aracı değişkenin \% 95 güven aralığında dolaylı etkisi incelendiğinde, kendini onaylamama şeması için BootLLCI $\mathrm{ken}_{=} .00$; BootULCIken= .09 olarak hesaplanmıştır. \% 95 güven aralığındaki bootstrap alt (BootLLCI) ve üst (BootULCI) değerleri arasında sıfır bulunmadığından, kendini onaylamama şemasının bu modelde anlamlı bir aracılık rolünün olduğu tespit edilmiştir. Aracılık etkisinin tam standardize etki büyüklüğü değeri olan $K^{2}$ ken= .05, aracılık etkisinin orta değere yakın bir etkiye sahip olduğunu göstermektedir. Aracı Model 4'ün grafiksel gösterimine Şekil 5'te yer verilmiştir. 


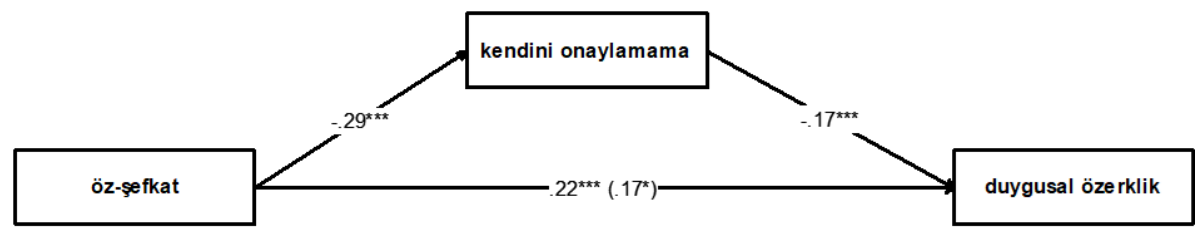

${ }^{*} \mathrm{p}<.05,{ }^{* *} \mathrm{p}<.01,{ }^{* \star *} \mathrm{p}<.001$

Şekil 5. Öz-Şefkat ile Duygusal Özerklik Arasındaki İlişkide Diğerleri

Yönelimlilik Şema Alanının Aracı Rolü (Aracı Model 4)

\section{Model 5- Aşırı Tetikte Olma/Bastırılmışlık Şema Alanının Aracı Rolü}

Tablo 6. Öz-Şefkat ile Duygusal Özerklik Arasındaki İlişkide Aşırı Tetikte Olma/Bastırılmışlık Şema Alanının Aracı Rolü

\begin{tabular}{|c|c|c|c|c|c|c|c|c|c|}
\hline \multirow[t]{2}{*}{ Aracı Model 5} & \multicolumn{3}{|c|}{$\begin{array}{l}\text { Karamsarlık } \\
\text { (M1) }\end{array}$} & \multicolumn{3}{|c|}{$\begin{array}{l}\text { Cezalandiricılik } \\
\text { (M2) }\end{array}$} & \multicolumn{3}{|c|}{$\begin{array}{l}\text { Duygusal Özerklik } \\
\text { (Y) }\end{array}$} \\
\hline & $\beta$ & $\mathrm{SE}$ & $t$ & $\beta$ & $\mathrm{SE}$ & $t$ & $\beta$ & SE & $t$ \\
\hline Öz-şefkat (X) & -.57 & .03 & -14.69 & -.25 & .01 & -12.65 & .14 & .04 & 3.02 \\
\hline M1 & - & - & - & - & - & - & -.16 & .04 & -3.59 \\
\hline M2 & - & - & - & - & - & - & .03 & .08 & .35 \\
\hline \multirow[t]{2}{*}{ Sabit } & 43.07 & 1.36 & 31.48 & 20.98 & .69 & 30.15 & 37.30 & 2.09 & 17.79 \\
\hline & \multicolumn{3}{|c|}{$\begin{array}{l}R^{2}=.28, F_{(1,554)}=46.22 \\
p<.01\end{array}$} & \multicolumn{3}{|c|}{$\begin{array}{l}R^{2}=.22, F_{(1,554)}=160.14 \\
p<.01\end{array}$} & \multicolumn{3}{|c|}{$\begin{array}{l}R^{2}=.08, F_{(3,552)}=16.17, \\
p<.01\end{array}$} \\
\hline \multirow{2}{*}{\multicolumn{4}{|c|}{ Dolaylı Etkiler için Bootstrap Sonuçları }} & & & & Boot & Boot & Boot \\
\hline & & & & & & $\beta$ & SE & LLCI & ULCI \\
\hline \multicolumn{4}{|c|}{ Toplam Dolaylı Etki } & & & .08 & .02 & .02 & .14 \\
\hline \multicolumn{3}{|c|}{ Dolaylı Etkiler } & \multicolumn{3}{|c|}{ Karamsarlık } & .09 & .02 & .04 & .14 \\
\hline \multicolumn{3}{|l|}{ Dolaylı Etkiler } & \multicolumn{3}{|c|}{ Cezalandırıcılık } & -.00 & .02 & -.05 & .03 \\
\hline
\end{tabular}

Tablo 6'da, öz-şefkat $(\mathrm{X})$ ile duygusal özerklik (Y) arasında aracı değişken olan aşırı tetikte olma/bastırılmışlık şema alanının (karamsarlıkM1 ve cezalandırıcılık-M2) etkisini gösteren regresyon analizi sonuçlarına yer verilmiştir. Buna göre, öz-şefkatin, karamsarlık şemasını $(\beta=-.57 ; t=-14.69 ; p<.05)$ ve cezalandırıcılık şemasını negatif yordadığ 1 $(\beta=-.25 ; t=-12.65 ; \beta<.05)$; duygusal özerkliği ise pozitif yordadığ $(\beta=.14$; $t=3.02 ; \beta<.05)$ belirlenmiştir. Öte yandan duygusal özerkliği, karamsarlık şemasının negatif yordadığı $(\beta=-.46 ; t=-3.59 ; \beta<.05)$, cezalandırıcılık şemasının ise yordamadığı $(\beta=.03 ; t=.35 ; p>.05)$ tespit edilmiştir. Bu bağlamda aracı değişkenlerin \% 95 güven aralığında dolaylı etkileri incelendiğinde, karamsarlık şeması için BootLLCI $\mathrm{kar}=.04$; BootULCI $\mathrm{kar}=$ .14 olarak hesaplanmıştır. \% 95 güven aralığındaki bootstrap alt (BootLLCI) ve üst (BootULCI) değerleri arasında sıfır bulunmadığından, 
karamsarlık şemasının bu modelde anlamlı bir aracılık rolünün olduğu tespit edilmiştir. Aracılık etkisinin tam standardize etki büyüklüğü değeri olan $K^{2}{ }_{\mathrm{kar}}=.09$, aracllık etkisinin orta değere yakın bir etkiye sahip olduğunu göstermektedir. Aracı Model 5'in grafiksel gösterimine Şekil $6^{\prime}$ da yer verilmiştir.

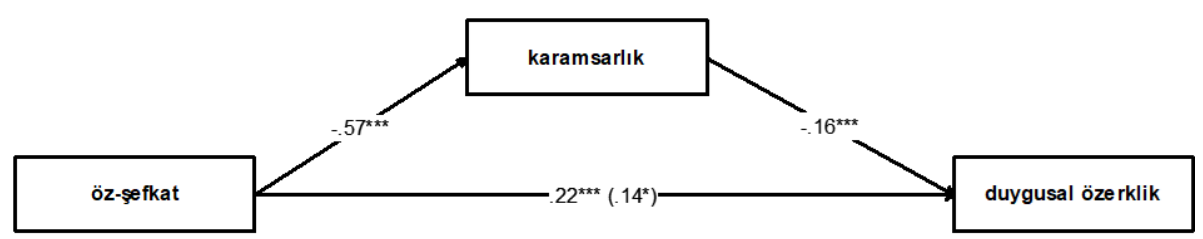

${ }^{*} \mathrm{p}<.05, "{ }^{* *}<.01,{ }^{* * *} \mathrm{p}<.001$

Şekil 6. Öz-Şefkat ile Duygusal Özerklik Arasındaki İlişkide Aşırn Tetikte

Olma/Bastırılmışlık Şema Alanının Aracı Rolï (Aracı Model 5)

\section{Tartışma ve Sonuç}

Araştırmada, öz-şefkat ile duygusal özerklik arasındaki ilişkide kopukluk-reddedilmişlik şema alanında yer alan duygusal yoksunluk; zedelenmiş özerklik ve performans alanında başarısızlık ve yapışıklık; zedelenmiş sınırlar şema alanında yetersiz özdenetim; diğerleri yönelimlilik şema alanında kendini onaylamama ve aşırı tetikte olma/bastırılmışlık şema alanında ise karamsarlık erken dönem uyumsuz şemasının aracılık etkisinin olduğu tespit edilmiştir. İlgili alanyazın incelendiğinde, bu modelin sınandığı bir araştırma bulgusuna rastlanmamıştır. Ancak güncel araştırmadaki modellere benzer şekilde, ergenlerde şema alanları ve erken dönem uyumsuz şemaların çeşitli değişkenler arasındaki aracılık etkisinin incelendiği gözlenmiştir. Ergenlerle yapılan araştırmalarda bağlanma ilişkileri ile depresif belirtiler (Roelofs vd., 2011), psikopatoloji (Bosmans vd., 2010) ve psikolojik belirtiler (Roelofs vd., 2013) arasındaki ilişkide şema alanları ve erken dönem uyumsuz şemaların aracı rolü incelenmiştir. Söz konusu araştırmalarda, ergenlerin bağlanma ilişkilerinde erken dönem uyumsuz şemaların önemli etkileri olduğu göze çarpmaktadır. Yetişkinlerle yapılan araştırmalarda da şema alanlarının yineleyici düşünceler 
(ruminasyon), kayg1 ve depresif belirtiler (Balsamo vd., 2015; Carlucci vd., 2018) için önemli belirleyici olduğu görülmektedir.

Öz-şefkat ile erken dönem uyumsuz şemaların birlikte incelendiği araştırmalarda ise, güncel çalışmadan farklı olarak, öz-şefkatin aracı rolü sınanmıştır. Yetişkin bireylerle gerçekleştirilen bu araştırmalarda, erken dönem uyumsuz şema alanları ile ikincil travmatik stres (Güzey, 2020), yaşam doyumu (Yakın, 2015; Yakın vd., 2019), ayrılık uyumu (Fırınc1, 2019), yaşam kalitesi (Besharat, Keshavarz ve Lavasani, 2015) ve psikolojik sıkıntı (Thimm, 2017) arasındaki ilişkilerde öz-şefkatin aracı rolü olduğu belirtilmiştir.

Güncel araştırmada, kopukluk-reddedilmişlik şema alanında yer alan duygusal yoksunluk şemasının öz-şefkat ile duygusal özerklik arasındaki ilişkide yüksek düzeyde aracılık etkisinin olduğu; kusurluluk, kuşkuculuk ve terk edilme şemalarının ise söz konusu ilişkiye aracılık etmediği tespit edilmiştir. Kusurluluk şemasına sahip bireylerin, kusurlu, itici ve değersiz olduğuna inandığı ve eleştiri ve suçlanmaya karşı aşırı duyarlı olduğu belirtilmektedir (Young ve Klosko, 2011). Kuşkuculuk/kötüye kullanılma şemasına sahip bireyler, diğer insanlardan her an zarar görebileceğine inanmakta ve bu nedenle diğerlerinin kendisine çok fazla yaklaşmasına izin vermeden yüzeysel ilişkiler kurmaktadır. Terk edilme şemasına sahip bireylerin ise er ya da geç tek başına kalacakları düşünceleri, onların ilişki kurarken tutarsız ve dengesiz davranışlar sergilemesine neden olmaktadır (Young vd., 2003; Young ve Klosko, 2011). Ergenlik döneminde bireylerin başta beden imajı olmak üzere kendisi ile ilgili özellikleri beğenmemesi ve akranlarıyla kıyaslayarak sürekli kendini küçük görmesi sıklıkla gözlenmektedir (Loose vd., 2018). Ayrıca diğerleri tarafından gülünç bulunacağ1 ve küçük düşürüleceği endişesiyle ergenlerin sosyal ortamlardan uzak durduğu ifade edilmektedir (Henderson ve Zimbardo, 1998). Bu durumda, bireyin kendini beğenmemesi ve eleştiriye karşı aşırı duyarlı olması ergenliğin doğası gereği yaşanabilir. Öte yandan, duygusal özerklik, ergenin bireyleşmesi, ebeveyn ve akranlardan bağımsızlaşması olarak tanımlanmaktadır (Noom, 1999). Bu bireyleşme ve bağımsızlaşma sürecinde bireyin kendine odaklanması, yalnızlaşması ve diğerleriyle olan ilişkilerini asgari seviyelere düşürmesi beklenebilir. Ayrıca, ergenlik döneminde duyguların şiddet ve yönünün değişkenlik 
gösterdiği ve tutarlı bir örüntü izlenimi vermediği belirtilmektedir (Steinberg, 2013). Bu doğrultuda, ergenlik döneminde bireyin kendine yönelmesi ve diğerleriyle olan ilişkilerinin zayıflaması beklenebilir. Sonuç olarak, yukarıda ifade edilen ergenlik dönemi gelişim özellikleri ile kusurluluk, kuşkuculuk ve terk edilme şemalarının içerik ve yapılarının benzer olması nedeniyle, söz konusu şemalar ergenlik döneminde ayrışmamış ve bu nedenle lise öğrencilerinde öz-şefkat ve duygusal özerkliğe etki etmemiş olabilir.

Kopukluk-reddedilmişlik şema alanı; güvenlik, bakım, sevgi ve aidiyet eksikliği ile ilişkilidir. Duygusal yoksunluk şeması ise; başkaları tarafından özel biri olarak algılanmayacağı, zor anlarında yanında olunmayacağı ve duygusal ihtiyaçlarının diğer insanlar tarafından hiçbir zaman yeterince karşılanmayacağı gibi inançlarla kendini göstermektedir (Young vd., 2003). Duygusal yoksunluk şemasına sahip bireylerin, kişiler arası ilişkilerde, narsisist bir eğilimle sürekli ilgi beklediği ve hiçbir zaman anlaşılmayacağı hissi nedeniyle duygu paylaşımı ve empatiden yoksun olduğu belirtilmektedir (Young ve Klosko, 2011). Bu yönüyle, söz konusu şemaya sahip bireylerin diğer insanlara karşı anlayışlı ve şefkatli olmayacağı öngörülebilir. Başkalarına karşı hissedilen şefkatin, kişinin kendisine yönlendirmesi ile öz-şefkatini geliştirilebileceği ifade edilmektedir (Germer, 2020). Bu durumda başkalarına şefkat göstermeyen ve ilgi görme konusunda israrcı olan bireylerde öz-şefkat gelişiminin olumsuz etkileneceği ve öz-şefkatin duygusal özerklik üzerindeki etki gücünün azalacağı düşünülebilir.

Zedelenmiş özerklik ve performans şema alanında yer alan başarısızlık ve yapışıklık şemalarının öz-şefkat ile duygusal özerklik arasındaki ilişkide orta düzeyde aracılık etkisinin olduğu tespit edilmiştir. Zedelenmiş özerklik ve performans şema alanı, bireyin kendini ebeveyn figürlerinden farklılaştırmada ve bağımsız davranmada zorluk yaşamasıyla ilişkilidir. Çocukken aşırı korunan ya da ihmal edilen bireylerde bu şema alanı görülmektedir (Young vd., 2003). Başarısızlık şemasına sahip olan birey, başarı gerektiren okul, spor, iş gibi alanlarda yetersiz olduğuna inanmaktadır. Bu başarısızlık algısı nedeniyle birey kendini aptal, yeteneksiz beceriksiz gibi olumsuz sıfatlarla nitelemekte ve başarılı olabileceği alanlardan da uzak durma eğilimi göstermektedir (Young ve Klosko, 2011; Young, Klosko ve Weishaar, 2009). Öz şefkat, 
bireyin yetersiz ve başarısız hissettiği durumlarda kendisine sıcaklık ve anlayış göstermesi şeklinde ifade edilmektedir (Neff, 2003a). Bu durumda, başarısızlık şemasına sahip bireyin kendisine şefkat yerine acımasız eleştiriler yöneltmesi sonucu öz-şefkat gelişiminin olumsuz etkileneceği ve öz-şefkatin duygusal özerklik üzerindeki etki gücünün azalacağı düşünülebilir.

Yapışıklık şeması, bireyin bir veya daha çok kişiye (genelde ebeveynlerden biri) aşırı duygusal bir bağla bağlanması ve o kişi olmadan kendini bir birey olarak düşünememesi şeklinde ifade edilmektedir (van Vreeswijk, Broarsen ve Nadort, 2012; Young vd., 2009). Duygusal anlamda bağımlı olan ve sürekli bağlı olduğu kişi/kişilere ihtiyaç duyan bireyin benliğini fark etmesi ve kendi duygu ve düşüncelerini tanıması zorlaşabilir. Ayrıca, Türk kültürü gibi kolektivist dokuya sahip olan kültürlerde, bireyler benlik kavramını başkalarına bağlı olarak tanımlamakta ve ilişkisel anlamda bağımsızlık yerine karşılıklı bağımlılığı tercih etmektedir (Mesquita, 2001; Triandis ve Suh, 2002). Bu durumda, yapışıklığı bir problemden ziyade gereklilik olarak değerlendiren bireyin kendi duygu ve düşüncelerine yönelmemesi sonucu öz-şefkat gelişiminin olumsuz etkileneceği ve özşefkatin duygusal özerklik üzerindeki etki gücünün azalacağ düşünülebilir.

Zedelenmiş sınırlar şema alanında yer alan yetersiz özdenetim şemasının öz-şefkat ile duygusal özerklik arasındaki ilişkide orta düzeyde aracılık etkisinin olduğu; haklılık şemasının ise söz konusu ilişkiye aracılık etmediği tespit edilmiştir. Üstünlük konusuna abartılı bir şekilde odaklanan haklılık şeması, bireylerin her durumda kendini haklı görmesine ve diğerlerine zarar verse dahi kendi isteklerini gerçekleştirmeye hakkı olduğu yönünde inanç geliştirmesine neden olmaktadır (Young ve Klosko, 2011). Ergenlik döneminde gelişen benmerkezcilikle birlikte, bireyin kendini dünyanın merkezindeymiş gibi algılaması (kişisel efsane) ve herkesin seyrettiği özel bir insan olduğunu düşünmesi (hayali seyirci), bu dönemde sıklıkla gözlenen bir durumdur (Sevim, Doğan Laçin, Aşçıŏlu Önal ve Avşar, 2019). Bu doğrultuda, kendini diğerlerinden üstün gören ve benzersiz olduğunu düşünen bireyin her konuda haklı olduğu gibi bir çıkarım yapması beklenebilir. Ayrıca, duygusal özerklikteki bireyleşme ve kendine 
odaklanma, ergen benmerkezciliğinin etkisini artırabilir. Sonuç olarak, yukarıda ifade edilen ergenlik dönemi gelişim özellikleri nedeniyle, haklılık şeması ergenlik döneminde ayrışmamış ve bu nedenle lise öğrencilerinde öz-şefkat ve duygusal özerkliğe etki etmemiş olabilir.

Erken yaşlarda son derece müsamahakâr ve izin verici ebeveynlere maruz kalma sonucunda oluşan zedelenmiş sınırlar şema alanı; öz disiplin için yeterli iç sınırlar oluşturma, başkalarının haklarına saygı duyma ve uzun vadeli hedefleri gerçekleştirme konusunda yaşanan zorluklarla ilişkilidir (Young vd., 2003). Yetersiz özdenetim şemasına sahip bireyler, anlık doyumları gelecekte elde edilecek kazanımlara tercih ederken; dürtü sinırlandırmasında sorun yaşayabilmektedir. Ayrıca bu bireylerin, uzun vadeli planlara uyma ve bunun için çalışmalar yapma konusunda zorlandığı; sıkıntılardan, yüzleşmelerden ve sorumluluk almaktan da sıklıkla kaçındıkları bilinmektedir (Güner, 2013; Young vd., 2003). Öz-şefkat; acı veren duygularla yüzleşme ve onları kucaklama gibi sorumluluk, sabır ve cesaret gerektiren bir başa çlkma becerisi şeklinde ifade edilmektedir (Germer, 2020). Bu durumda yetersiz özdenetim şemasına sahip bireyin duygusal olgunlaşma gibi zor ve uzun soluklu bir görevden kaçınması sonucu öz-şefkat gelişiminin olumsuz etkileneceği ve öz-şefkatin duygusal özerklik üzerindeki etki gücünün azalacağı düşünülebilir.

Diğerleri yönelimlilik şema alanında yer alan kendini onaylamama şemasının öz-şefkat ile duygusal özerklik arasındaki ilişkide orta düzeyde aracilık etkisinin olduğu tespit edilmiştir. Ebeveynlerden koşullu sevgiye maruz kalma sonucunda gelişen diğerleri yönelimlilik şema alanı; onay almak ve duygusal bağı sürdürmek için başkalarının ihtiyaçlarını kendi ihtiyaçlarından daha önemli görmeye neden olmaktadır. Dolayısıyla, başkalarının ihtiyaçlarına aşırı derecede odaklandıkça, bireylerin öfkeleri ve seçimleri hakkındaki öz farkındalıkları da azalmaktadır (Young vd., 2003). Kendini onaylamama şeması ise; diğerlerinin ihtiyaç ve özelliklerine odaklanma sonucunda kendi olumlu özelliklerini fark etmeme ve kendini beğenmeme eğilimi ile karakterizedir. Öz-şefkatin, bilinçli farkındalık ile birlikte çalıştığı ve öz-farkındalık düzeyi yüksek olan bireylerin öz-şefkatlerinin de yüksek olacağ1 ileri sürülmektedir (Germer, 2020). Bu durumda, kendini onaylamama şemasına sahip bireyin kendi ihtiyaç ve özelliklerine dair 
farkındalık düzeyinin düşük olması sonucu öz-şefkat gelişiminin olumsuz etkileneceği ve öz-şefkatin duygusal özerklik üzerindeki etki gücünün azalacağ 1 düşünülebilir.

Aşırı tetikte olma/bastırılmışlık şema alanında yer alan karamsarlık şemasının öz-şefkat ile duygusal özerklik arasındaki ilişkide orta düzeyde aracılık etkisinin olduğu; cezalandırıcılık şemasının ise söz konusu ilişkiye aracılık etmediği tespit edilmiştir. Öfke ve acımasızlığın yoğun şekilde yer aldığı bu şema, hafifletici sebepler olsa bile bireyin kendisi ya da diğerlerinin hatalarını affetme konusunda olumsuz bir tutum sergilemesine neden olmaktadır (Young vd., 2003). Ergen bireylerin, mutluluk ve neşeye karşı, hüzün ve melankoli ve şefkatli olmaya karşı, acımasızlık gibi birbiriyle çelişen eğilimler sergilediği belirtilmektedir (Adams, 2000). Duygu durumlarda ani değişimlerin sıkça yaşandığı bu dönemde, bireylerin kendilerini suçlama davranışları da artmaktadır (Loose vd., 2018). Bu doğrultuda, bireyin yapılan hatalara karşı anlayışlı olmaması ve ani değişen duygu durumlar nedeniyle doğru yanlış konusunu sağlıklı değerlendirememesi beklenebilir. Sonuç olarak, yukarıda ifade edilen ergenlik dönemi gelişim özellikleri nedeniyle, cezalandırıcılık şeması ergenlik döneminde ayrışmamış ve bu nedenle lise öğrencilerinde öz-şefkat ve duygusal özerkliğe etki etmemiş olabilir.

Baskı altında hissetme ve kendisine karşı aşırı eleştirel davranmanın yaygın olduğu bu şema alanında, bireylerin, onaylanmama veya utanç duygusunu önlemek için son derece yüksek içselleştirilmiş standartlarına ulaşma eğiliminde olduğu belirtilmektedir (Young vd., 2009). Hayatın olumlu yanlarını küçümseyerek olumsuz yanlarına odaklanma ve her şeyin kötüye gideceğine inanma şeklinde ifade edilen karamsarlık şeması (Young vd., 2003), bireylerin kaygılı, kararsız ve şikayetçi olmalarına neden olabilir. Olumsuz duyguların bireyi esir almaması ve öz-şefkatin etkili olabilmesi için duygulara gerçekçi yaklaşılması ve doğru bir mesafede olunması gerektiği ifade edilmiştir (Sarıcaoğlu, 2011). Bu durumda karamsarlık şemasına sahip olan bireyin gerçekçilikten uzak bir şekilde sadece olumsuz duygulara odaklanması sonucu öz-şefkat gelişiminin olumsuz etkileneceği ve öz-şefkatin duygusal özerklik üzerindeki etki gücünün azalacağı düşünülebilir. 
Ebeveynlerden ayrışma ve duygusal bağımsızlık kazanma, ergenlik döneminin önemli gelişim görevlerinden biridir (Loose vd., 2018). Bu dönemde, duyguların şiddet ve yönünün sürekli değiştiği, çoğunlukla tutarlı bir örüntü izlenimi vermediği ve bu nedenle ergenlerin duygu yönetimi becerilerinin düşük olduğu ifade edilmektedir (Steinberg, 2013). Duygu düzenlemede tamamlayıcı bir kavram olduğu ileri sürülen (Neff vd., 2007) öz-şefkatin, duyguları yönetme, duygusal olgunluğa ulaşma ve duygusal bağımsızlık kazanma konusunda ergen bireylere katkı sağlayacağı düşünülmektedir. Bir tür duygu düzenleme tekniği olduğu da kabul edilen (Diedrich vd., 2014) öz-şefkat, gerçekçi bir bakış açısı ve objektif bir duruşla olumsuz olaylara karşı güvenli bir duygusal mesafe oluşturmaktadır (Finlay-Jones, Rees ve Kane, 2015). Öz-şefkat, olumsuz duyguları olumlu duygularla değiştirmek yerine; olumsuz duyguları kucaklayarak olumlu duyguların daha etkili olmasını kolaylaştırmaktadır (Barlow, Turow ve Gerhart, 2017; Neff, 2003a). Özşefkatle birlikte, ergen bireylerin dönemsel gelişim krizleriyle daha etkili şekilde başa çıabilecekleri ve ebeveynlerden ayrışma ve duygusal bağımsızlık kazanma gelişim görevini sağlıklı şekilde tamamlayabilecekleri söylenebilir. Ayrıca zor ve karmaşık durumlarda sorumluluk üstlenme, cesaretli olma, mücadele etme ve kendine anlayış gösterme gibi olumlu davranışları içinde barındıran öz-şefkat (Germer, 2020; Neff, 2003a), duygusal özerkliğin gelişimine katkı sağlayabilir. Güncel araştırmada elde edilen "öz-şefkatin duygusal özerkliğin anlamlı bir yordayıcısı olduğu" bulgusu, bu düşünceyi desteklemektedir.

Ancak, erken dönem uyumsuz şemaların bir kaynağ 1 olduğu ileri sürülen erken olumsuz deneyimlerin (Young, 1999) öz-şefkatin varlığ1 için tehlike oluşturduğu ileri sürülmektedir (Germer, 2020). Erken dönem uyumsuz şemaların sadece çocukluk döneminde gelişmediği, aynı zamanda yaşam boyunca da detaylandırılmaya devam ettiği belirtilmektedir (Young vd., 2003). Masomi vd., (2014), bireylerin duygusal tepkilerinin psikopatolojiye katkıda bulunan erken dönem uyumsuz şemaların çizdiği kurallara göre belirlendiğini ifade etmektedir. $\mathrm{Bu}$ nedenle, şemaların tetiklenmesi sonucu olumsuz duyguların gücünün artması ve öz-şefkatin etkisinin azalması beklenebilir. Güncel araştırmada elde edilen, “öz-şefkat ile duygusal özerklik arasındaki ilişkide, tüm şema alanlarının anlamlı aracılık rolü 
olduğu ve erken dönem uyumsuz şemaların öz-şefkatin duygusal özerklik üzerindeki etkiyi azalttı̆̆ı" bulgusu, bu düşünceyi desteklemektedir.

Araştırma sonuçları; lise öğrencilerinde öz-şefkat ile duygusal özerklik arasındaki ilişkide erken dönem uyumsuz şemaların aracı rolünün olduğunu göstermektedir. Bu sonuç doğrultusunda, duygusal yoksunluk, başarısızlık, yapışıklık, yetersiz özdenetim, kendini onaylamama ve karamsarlık şemalarının, ergen bireylerde öz-şefkatin duygusal özerklik gelişimine sağladığı katkıyı azaltacağı söylenebilir. Bu bilgiden hareketle, duygusal özerkliğe uzanan yolda, erken dönem uyumsuz şemaların başka hangi kavramlar üzerinde etkili olduğunu belirleyecek kapsamlı araştırmalar yapılabilir. Ayrıca, lise öğrencilerinde erken dönem uyumuşuz şemaların etkisini azaltma ve öz-şefkati artırmaya yönelik şema terapi odaklı bireysel ve grupla psikolojik danışma oturumları ve psikoeğitim programları uygulanması önerilebilir. Bunun yanında, ebeveynlere duygusal özerklik gelişiminde öz-şefkatin etkisini azaltan erken dönem uyumsuz şemalar ve bu şemaların hangi koşullarda tetiklendiği konusunda bilgi ve eğitim verilebilir.

Çalışma grubunun bir il merkezinde devlet okullarında öğrenim görmekte olan 14-16 yaş grubundaki ergen bireylerden seçilmesi, araştırmanın ilişkisel bir çalışma olması ve araştırmada uygun örnekleme yönteminin kullanılması araştırmanın sınırlılıkları olarak ifade edilebilir. Bu bilgiler ışığında, 10-16 yaş grubundaki çocuk ve ergenlerden, özel okullardan ve farklı il ve bölgelerden oluşacak daha büyük örneklemler üzerinde yapılacak olan araştırmalar ve erken dönem uyumsuz şemaların öz-şefkat ve duygusal özerklik üzerindeki etkisinin sinanacağı deneysel çalışmalar, bu araştırma bulgularının genellenebilirliği açısından önem taşımaktadır. 


\section{EXTENDED ABSTRACT The Mediating Role of Early Maladaptive Schemas in the Relationship between Self-Compassion and Emotional Autonomy in High School Students}

*

Lokman Koçak- Eyüp Çelik

Sakarya University

Separation from parents and gaining emotional independence is one of the important developmental tasks of adolescence (Loose et al., 2018). It is stated that in this period, the intensity and direction of emotions change constantly, often do not give the impression of a consistent pattern, and therefore, adolescents' emotion management skills are low (Steinberg, 2013). The individual who feels the need to be more selfsufficient and free during adolescence; It is stated that with emotional autonomy, they begin to make their own decisions and manage their emotions and behaviors (Zimmer-Gembeck \& Collins, 2006). In addition, it is claimed that the development of autonomy is effective in the search for identity, creating one's self and increasing social interactions (Deniz et al., 2013). In this respect, it can be thought that emotional autonomy has an important role in the successful completion of critical developmental tasks such as gaining emotional independence, individuation and establishing relationships with peers and social environment. Self-compassion, which is claimed to be a complementary concept in emotion regulation (Neff et al., 2007), is thought to contribute to adolescents in managing emotions, reaching emotional maturity and gaining emotional independence.

Self-compassion, which is also accepted as a kind of emotion regulation technique (Diedrich et al., 2014), creates a safe emotional distance from negative events with a realistic perspective and objective stance (Finlay-Jones et al., 2015). Self-compassion does not replace negative emotions with positive ones; by embracing negative emotions, it facilitates positive emotions to be more effective (Barlow et al., 2017; Neff, 2003a). It can be said that with self-compassion, adolescent individuals can cope with periodical developmental crises more 
effectively and they can complete the developmental task of separation from parents and gaining emotional independence in a healthy way. In addition, self-compassion, which includes positive behaviors such as taking responsibility in difficult and complex situations, being courageous, struggling and showing self-understanding (Germer, 2020; Neff, 2003a), can contribute to the development of emotional autonomy.

However, it is argued that early negative experiences which are claimed to be a source of early maladaptive schemas (Young, 1999), pose a threat to the existence of self-compassion (Germer, 2020). It is stated that early maladaptive schemas do not only develop in childhood, but also continue to be elaborated throughout life (Young, et al. 2003). Masomi et al. (2014) state that the emotional reactions of individuals are determined according to the rules drawn by early maladaptive schemas that contribute to psychopathology. Therefore, it can be expected that the power of negative emotions will increase and the effect of selfcompassion will decrease as a result of triggering of schemas. In this respect, it is thought that it is important to determine the effect of early maladaptive schemas on the relationship between self-compassion and emotional autonomy in adolescents. In this context, this study focuses on the mediating role of early maladaptive schemas in the relationship between self-compassion and emotional autonomy in high school students.

The study group consists of a total of 556 high school students, 296 female $(53.2 \%)$ and 260 male (46.8\%), who were studying at different high schools in Kocaeli province in 2019-2020 academic year. The participants were aged between 14 and 16, with an average age of 15.2. As data collecting tools, Emotional Autonomy Scale for Adolescents, The Self-compassion Scale for Adolescents and Early Maladaptive Schema Questionnaires Set for Children and Adolescents between the Ages of 1016 were used.

In the study, the relationships between self-compassion, emotional autonomy, and early maladaptive schemas were examined using regression-based mediation analysis and correlation analysis. Furthermore, a bootstrap method was used to examine the direct and indirect effects in the mediation models. According to the relevant literature, mediation models were established by taking the schema areas 
into consideration, and the mediating role of early maladaptive schemas was tested accordingly.

According to the results of the correlation analysis, there is a significant relationship between self-compassion and all early maladaptive schemas $(p<.05)$. In addition, it was determined that there was no significant relationship between emotional autonomy and dependence, vulnerability, subjugation and approval seeking $(p>.05)$, and there was a significant relationship between other early maladaptive schemas and emotional autonomy $(p<.05)$. As a result of mediation analysis, it has been determined that the schema of emotional deprivation in the disconnection-rejection schema area, schema of failure and enmeshment/undeveloped self in impaired autonomy and performance schema area, schema of insufficient self-control in impaired limits schema area, schema of self-disapproval in other-directedness schema area, and schema of pessimism overvigilance/inhibition schema area have a mediating effect on the relationship between self-compassion and emotional autonomy.

Current study shows that early maladaptive schemas have a mediating role in the relationship between self-compassion and emotional autonomy in high school students. In line with this result, it can be said that emotional deprivation, failure, enmeshment/undeveloped self, insufficient self-control, self-disapproval and pessimism schemas will reduce the contribution of self-compassion to the development of emotional autonomy in adolescents.

\section{Kaynakça / References}

Adams, G. (2000). Adolescent development the essential readings. New Jersey: Blackwell Publishers.

Akman, Y., Abaslı, K. ve Polat, Ş. (2018). Duygusal özerklik, öğrenci yılmazlı̆̆1, öğretmene güven ve problem çözme becerilerine yönelik alg1 arasındaki ilişkilerin öğrenci görüşlerine göre incelenmesi. Gazi Üniversitesi Gazi Eğitim Fakültesi Dergisi, 38(3), 987-1012. DOI: 10.17152/gefad.397455 
Ayas, T. ve Pişkin, M. (2011). Lise öğrencileri arasındaki zorbalık olaylarının cinsiyet, sınıf düzeyi ve okul türü bakımından incelenmesi. İlköğretim Online, 10(2), 550-568.

Balsamo, M., Carlucci, L., Sergi, M. R., Klein Murdock, K. and Saggino A. (2015). The mediating role of early maladaptive schemas in the relation between co-rumination and depression in young adults. PLoS ONE, 10(10), 1-14. DOI: 10.1371/journal. pone.0140177

Barlow, M. R., Turow, R. E. G. and Gerhart, J. (2017). Trauma appraisals, emotion regulation difficulties, and self-compassion predict posttraumatic stress symptoms following childhood abuse. Child Abuse \& Neglect, 65, 37-47. DOI: 10.1016/j.chiabu.2017.01.006

Bayramoğlu, A. (2011). Self-compassion in relation to psychopathology (Doctoral Dissertation). Orta Doğu Teknik Üniversitesi, Sosyal Bilimler Enstitüsü, Ankara.

Bektaş, D. Y. (2004). Ergenlerde beden imgesi üzerine bir çalışma. Türk Psikolojik Danışma ve Rehberlik Dergisi, 3(22), 67-75.

Besharat, M. A., Keshavarz, S. and Lavasani, M. G. (2015). Mediating role of self-compassion and self-control in the relationship between early maladaptive schemas and quality of life. Developmental Pschology: Iranian Psychologists, 11(44), 341-355.

Beyers, W. and Goossens, L. (1999). Emotional autonomy, psychosocial adjustment and parenting: Interactions, moderating and mediating effects. Journal of Adolescence, 22, 753-769. DOI: 10.1006/jado.1999.0268

Bosmans, G., Braet, C. and Vlierberghe, L. V. (2010). Attachment and Symptoms of Psychopathology: Early Maladaptive Schemas as a Cognitive Link? Clinical Psychology and Psychotherapy, 17, 374-385. DOI: $10.1002 /$ cpp. 667

Burwell, R. A. and Shirk, S. R. (2006). Self processes in adolescent depression: The role of self-worth contingencies. Journal of Resarch on Adolescence, 16, 479-490. DOI: 10.1111/j.1532-7795.2006.00503.x

Büyüköztürk, Ş. (2019). Sosyal bilimler için veri analizi el kitabı: İstatistik, araştırma deseni SPSS uygulamaları ve yorum (Geliştirilmiş 26. Baskı). Ankara: Pegem Akademi.

Carlucci, L., D'Ambrosio, I., Innamorati, M., Saggino, A. and Balsamo, M. (2018). Psychology Research and Behavior Management, 11, 133-144. DOI: 10.2147/PRBM.S144907. 
Chen, Z. Y. and Dornbusch, S. M. (1998). Relating aspects of adolescent emotional autonomy to academic achievement and deviant behavior. Journal of Adolescent Research, 13, 293-319. DOI: 10.1177/0743554898133004

Cicognani, E. and Zani, B. (2014). Alcohol use among Italian university students: The role of sensation seeking, peer group norms and selfefficacy. Journal of Alcohol and Drug Education, 55(2), 17-36.

Deniz, M., Çok, F. ve Duyan, V. (2013). Ergenlikte özerklik: Duygusal Özerklik Ölçeği'nin ergenler için uyarlanması ve yapı geçerliği çalışması. Eğitim ve Bilim, 38(167), 352-363.

Diedrich, A., Grant, M., Hofmann, S. G., Hiller, W. and Berking, M. (2014). Self-compassion as an emotion regulation strategy in major depressive disorder. Behaviour Research and Therapy, 58, 43-51. DOI: 10.1016/j.brat.2014.05.006

Diehm, R. and Armatas, C. (2004). Surfing: An avenue for socially acceptable risk-taking, satisfying needs for sensation seeking and experience seeking. Personality and Individual Differences, 36, 663-677. DOI: 10.1016/S0191-8869(03)00124-7

Donohew, L., Zimmerman, R. S., Cupp, P. S., Novak, S., Colon, S. and Abell, R. (2000). Sensation seeking, impulsive decision-making, and risky sex: Implications for risk-taking and design of interventions. Personality and Individual Differences, 28, 1079-1091. DOI: 10.1016/S0191-8869(99)00158-0

Dunn, M., Tarter, R. E., Mezzich, A. C., Vanyukov, M., Kirisci, L. and Kirillova, G. (2002). Origins and consequences of child neglect in substance abuse families. Clinical Psychology Review, 22(7), 1063-1090. DOI: 10.1016/s0272-7358(02)00132-0

Erçevik A. (2014). Lise öğrencilerinin duygusal özerklik ve sosyal destek düzeyleri arasındaki ilişkinin incelenmesi (Yüksek Lisans Tezi). İstanbul Üniversitesi, Eğitim Bilimleri Enstitüsü, İstanbul.

Eskin, M., Ertekin, K., Harlak, H. ve Dereboy, Ç. (2008). Lise öğrencisi ergenlerde depresyonun yaygınlığı ve ilişkili olduğu etmenler. Türk Psikiyatri Dergisi, 19(4), 382-389.

Farrell, J. M., Reiss, N. and Shaw, I. A. (2015). Şema terapi: Klinisyenin rehberi (Çev. S. G. Alkan ve E. Alkan). İstanbul: Psikonet Yayınları (Orijinal çalışma basım tarihi 2014). 
Fırıncı, C. (2019). Öz şefkat, minnettarlık ve bağışlayıcllı̆̆ı erken dönem uyumsuz şemalar ve ayrilık uyumu arasındaki ilişkide aracı rolü: Bir karma yöntem araştırması (Yüksek Lisans Tezi). TED Üniversitesi, Sosyal Bilimler Enstitüsü, Ankara.

Finlay-Jones, A. L., Rees, C. S. and Kane, R. T. (2015). Self-compassion, emotion regulation and stress among Australian psychologists: Testing an emotion regulation model of self-compassion using structural equation modeling. PLOS ONE, 10(7). DOI: 10.1371/journal.pone.0133481

Germer, C. K. (2020). Öz şefkatli farkındalık: Tahrip edici duygularla başa çıkabilmek (Çev. H. Ü. Haktanır). İstanbul: Diyojen Yayıncılık (Orijinal çalışma basım tarihi 2009).

Gilbert, P. (2009). Introducing compassion-focused therapy. Advances in Psychiatric Treatment, 15, 199-208.

Gilbert, P. and Procter, S. (2006). Compassionate mind training for people with high shame and self-criticism: Overview and pilot study of a group therapy approach. Clinical Psychology and Psychotherapy, 13, 353-379. DOI: 10.1002/cpp.507

Gökçe, S., Önal Sönmez, A., Yusufoğlu, C., Yulaf, Y. ve Adak, İ. (2017). Erken dönem uyumsuz şemaların ergenlik dönemi depresif bozuklukla ilişkisi. Anadolu Psikiyatri Dergisi, 18(3), 283-291.

Güner, O. (2013). 10-16 Yaş Çocuk ve Ergenler için Erken Dönem Uyumsuz Şema Ölçekler Takımının (ÇEŞÖT) geçerlik, güvenirlik ve norm çalışması (Doktora Tezi). Marmara Üniversitesi, Eğitim Bilimleri Enstitüsü, İstanbul.

Güney, M. A. (2017). Ergenlerde duygusal özerklik, sosyal destek ve öznel iyi oluş arasindaki ilişkinin incelenmesi (Yüksek Lisans Tezi). Necmettin Erbakan Üniversitesi, Eğitim Bilimleri Enstitüsü, Konya.

Güzey, A. (2020). Erken dönem uyum bozucu şema alanlar ile mülteci yardım çalışanlarındaki ikincil travmatik stresi arasındaki ilişki üzerinde öz-şefkatin aracı rolü (Yüksek Lisans Tezi). Başkent Üniversitesi, Sosyal Bilimler Enstitüsü, Ankara.

Hayes, A. F. (2013). Introduction to mediation, moderation, and conditional process analysis: A regression-based approach. New York: Guilford Press.

Henderson L. and Zimbardo F. G. (1998). Syness. Encyclopedia of mental health. San Diego: Academic Press. 
Karasar, N. (2014). Bilimsel araştırma yöntemleri (26. Basım). Ankara: Nobel Yayınevi.

Kaya, Y. and Aydın, A. (2020). The mediating role of early maladaptive schemas in the relationship between attachment and mental health symptoms of university students. Journal of Adult Development, 28(5), 1-10. DOI: 10.1007/s10804-020-09352-2

Kendall-Tackett, K. (2002). The health effects of childhood abuse: Four pathways by which abuse can influence health. Child Abuse $\mathcal{E}$ Neglect, 26(6-7), 715-729. DOI: 10.1016/S0145-2134(02)00343-5

Koçak, L. (2020). Investigation of the relationship between early maladaptive schemas and academic expectations stress among high school students. Turkish Psychological Counseling and Guidance Journal, 10(57), 321-342.

Koçak, L. and Seçer, İ. (2018). Lise öğrencilerinde okul tükenmişliği ile depresyon ve kaygı arasındaki ilişkinin incelenmesi. Çukurova Üniversitesi Eğitim Fakültesi Dergisi, 47(2), 601-622. DOI: 10.14812/cuefd.372054

Loose, C., Graaf, P. and Zarbock, G. (2018). Çocuk ve ergenler için şema terapi (Çev. N. Azizlerli, Y. Yürüker, İ. G. Şan, Ö. Koç ve Z. Karabuda). İstanbul: Psikonet Yayınları (Orijinal çalışma basım tarihi 2013.)

Masomi, R., Hejazi, M. and Sobhi, A. (2014). The relationship between depression and early maladaptive schemas, obsessive rumination and cognitive emotion regulation. Indian Journal of Fundamental and Applied Life Sciences, 4 (S3), 1159-1170.

Mesquita, B. (2001). Emotions in collectivist and individualist contexts. Journal of Personality and Social Psychology, 80(1), 68-74. DOI: 10.1037/00223514.80.1.68

Neff, K. D. (2003a). Self-compassion: An alternative conceptualization of a healthy attitude toward oneself. Self and Identity, 2(2), 85-102. DOI: $10.1080 / 15298860390129863$

Neff, K. D. (2003b). The development and validation of a scale to measure selfcompassion. Self and Identity, 2(3), 223-250. DOI: 10.1080/15298860390209035

Neff, K. D., Kirkpatrick, K. L. and Rude, S. S. (2007). Self-compassion and adaptive psychological functioning. Journal of Research in Personality, 41(1), 139-154. DOI: 10.1016/j.jrp.2006.03.004 
Neff, K. D. and McGehee, P. (2010). Self-compassion and psychological resilience among adolescents and young adults. Self and Identity, 9(3), 225-240. DOI: $10.1080 / 15298860902979307$

Neff, K. D., Pisitsungkagarn, K. and Hsieh, Y. P. (2008). Self-Compassion and selfconstrual in the United States, Thailand, and Taiwan. Journal of Cross-Cultural Psychology, 39, 267-285. DOI: 10.1177/0022022108314544

Neff, K. D., Rude, S. S. and Kirkpatrick, K. L. (2007). An examination of selfcompassion in relation to positive psychological functioning and personality traits. Journal of Research in Personality, 41(4), 908-916. DOI: 10.1016/j.jp. 2006.08.002

Neff, K. D. and Vonk, R. (2009). Self-compassion versus global self-esteem: Two different ways of relating to oneself. Journal of Personality, 77(1), 23-50. DOI: $10.1111 / j .1467-6494.2008 .00537 . x$

Noom, M. J. (1999). Adolescent autonomy: Characteristic and correlates. Delft: Eburon.

Noom, M. J., Dekovic, M. and Meeus, W. H. J. (2001). Conceptual analysis and measurement of adolescent autonomy. Journal of Youth and Adolescence, 30, 577-595.

Özdemir, Y. ve Çok, F. (2011). Ergenlikte özerklik gelişimi. Türk Psikolojik Danışma ve Rehberlik Dergisi, 4(36), 152-164.

Öztürk, S. (2019). Ergenlerde bilişsel esneklik ve duygusal özerklik: bilişsel duygu düzenleme stratejilerinin aracı rolü (Yüksek lisans tezi). Çukurova Üniversitesi, Sosyal Bilimler Enstitüsü, Adana.

Özyürek, A. ve Demiray, K. (2010). Yurtta ve ailesi yanında kalan ortaöğretim öğrencilerinin kaygı düzeylerinin karşılaştırılması. Doğuş Üniversitesi Dergisi, 11(2), 247-256.

Pallant, J. (2017). SPSS kullanma kilavuzu: SPSS ile adım adım very analizi (2. Baskı). (Çev: S. Balcı ve B. Ahi). Ankara: Anı Yayıncılık.

Paxton, S. J., Schutz, H. K., Wertheim, E. H. and Muir, S. L. (1999). Friendship clique and peer influences on body image concerns, dietary restraint, extreme weight-loss behaviors, and binge eating in adolescent girls. Journal of Abnormal Psychology, 108(2), 255-266. DOI: 10.1037/0021843X.108.2.255

Plotnik, R. (2009). Psikolojiye giriş (Çev. T. Geniş). İstanbul: Kaknüs Yayınları.

Preacher, K. J. and Kelley, K. (2011). Effect size measures for mediation models: Quantitative strategies for communicating indirect effects. Psychological Methods, 16, 93-115. DOI: 10.1037/a0022658 
Raes, F., Pommier, E., Neff, K. D. and Van Gucht, D. (2011). Construction and factorial validation of a short form of the self-compassion scale. Clinical Psychology \& Psychotherapy, 18(3), 250-255. DOI: 10.1002/cpp.702

Ravndal, E., Lauritzen, G., Frank, O., Jansson, I. and Larsson, J. (2001). Childhood maltreatment among norwegian drug abusers in treatment. International Journal of Social Welfare, 10(2), 142-147. DOI: 10.1111/1468-2397.00164

Rendon, K. P. (2006). Understanding alcohol use in college students: A study of mindfulness, self-compassion, and psychological symptoms (Doctoral Dissertation). The University of Texas, Austin.

Richardson, G. (2005). Early maladaptive schemas in a sample of British adolescent sexual abusers: Implications for therapy. Journal of Sexual Aggression, 11(3), 259-276. DOI: 10.1080/13552600500402419

Roelofs, J., Onckels, L. and Muris, P. (2013). Attachment quality and psychopathological symptoms in clinically referred adolescents: The mediating role of early maladaptive schema. Journal of Child and Family Studies, 22, 377-385.

Roelofs, J., Lee, C., Ruijten, T. and Lobbestael, J. (2011). The Mediating Role of Early Maladaptive Schemas in the Relation between Quality of Attachment Relationships and Symptoms of Depression in Adolescents. Behavioural and Cognitive Psychotherapy, 39, 471-479. DOI: 10.1017/S1352465811000117

Russell, S. T. and Bakken, R. J. (2002). Development of autonomy in adolescence. Cooperative Extension, Institute of Agriculture and Natural Resources, University of Nebraska-Lincoln.

Sarıcaoğlu, H. (2011). Üniversite öğrencilerinde psikolojik iyi olma düzeylerinin kişilik özellikleri ve öz anlayış açısından incelenmesi (Yüksek Lisans Tezi). Selçuk Üniversitesi Eğitim Bilimleri Enstitüsü, Konya.

Sarıtaş, D. ve Gençöz, T. (2011). Psychometric properties of "Young schema questionnaire-short form 3 " in a Turkish adolescent sample. Journal of Cognitive and Behavioral Psychotherapies, 11(1), 83-96.

Sevim, S. A., Doğan Laçin, B. G., Aşçıŏlu Önal, A. ve Avşar, V. (2019). Farklı yaşlardaki gençlerin benmerkezlilik eğilimleri ve akılcı olmayan inançlarının karşılaştırılması. Ankara Üniversitesi Ĕ̆itim Bilimleri Fakültesi Dergisi, 52(3), 685-712. DOI: 10.30964/auebfd.521994

Steinberg, L. (2013). Ergenlik (Çev. F. Çok). Ankara: İmge Kitabevi. 
Steinberg, L. and Silverberg, S. B. (1986). The vicissitudes of autonomy in early adolescence. Child Development, 57, 841- 851.

Şencan, H. (2005). Sosyal ve davranışsal ölçümlerde güvenirlik ve geçerlik. Ankara: Seçkin Yayınları.

Tatar, A., Bildik, T., Yektaş, Ç., Hamidi, F. ve Özmen, H. E. (2016). Duygusal özerklik ölçeğinin Türkçe'ye uyarlanması ve klinik başvurusu olmayan ergen öğrencilerde duygusal özerkliğin incelenmesi. Nobel Medicus, 12(1), 39-48.

Thimm, J. C. (2017). Relationships between early maladaptive schemas, mindfulness, self-compassion, and psychological distress. International Journal of Psychology and Psychological Therapy, 17(1), 3-17.

Thompson, B. L. and Waltz, J. (2008). Self-compassion and PTSD symptom severity. Journal of Traumatic Stress, 21(6), 556-558. DOI: $10.1002 /$ jts.20374

Triandis, H. C. and Suh, E. M. (2002). Cultural influences on personality. Annual review of psychology, 53(1), 133-160.

van Vreeswijk, M., Broarsen, J. and Nadort, M. (Eds.). (2012). The wileyblackwell handbook of schema therapy: Theory, research, and practice. UK: A John Wiley \& Sons.

Vatan, S. (2019). Duygu düzenlemenin şahdamarı: Öz-şefkat. PiVOLKA, 9(31), $1-4$.

Vettese, L. C., Dyer, C. E., Li, W. L. and Wekerle, C. (2011). Does selfcompassion mitigate the association between childhood maltreatment and later emotion regulation difficulties? A preliminary investigation. International Journal Mental Health Addiction, 9, 480-491. DOI: 10.1007/s11469-011-9340-7

Wei, M., Liao, K. Y., Ku, T. and Shaffer, P. A. (2011). Attachment, SelfCompassion, Empathy, and Subjective Well-Being Among College Students and Community Adults. Journal of Personality, 79(1), 191-200. DOI: 10.1111/j.1467-6494.2010.00677.x

Wenar, C. and Kerig, P. (2000). Developmental psychopathology: From infancy through adolescence (4th ed.). New York: McGraw-Hill.

Yakın, D. (2015). Erken dönem uyumsuz şemalar ve iyi oluş arasındaki ilişkiye yönelik bütünleyici bir bakış: Erken dönem anılar, öz-şefkat ve duygu düzenleme (Doctoral Dissertation). ODTÜ, Sosyal Bilimler Enstitüsü, Ankara. 
Yakın, D., Gençöz, T., Steenbergen, L. and Arntz, A. (2019). An integrative perspective on the interplay between early maladaptive schemas and mental health: The role of self-compassion and emotion regulation. Journal of Clinical Psychology, 75, 1098-1113. DOI: 10.1002/jclp.22755

Yavuzer, H. (2000). Çocuk eğitimi el kitabı (4. Basım). İstanbul: Remzi Kitabevi.

Yıldırım, M. (2018). Ergenlere yönelik öz-şefkat geliştirme programının öz-şefkat, kendine şefkat vermekten korkma ve öznel iyi oluş üzerindeki etkililiğinin incelenmesi (Yüksek Lisans Tezi). Bolu Abant İzzet Baysal Üniversitesi, Eğitim Bilimleri Enstitüsü, Bolu.

Yıldırım, M. ve Sarı, T. (2018). Öz-şefkat ölçeği kısa formunun Türkçe uyarlaması: Geçerlik ve güvenirlik çalışması. Abant İzzet Baysal Üniversitesi Ĕ̆itim Fakültesi Dergisi, 18(4), 2502-2517.

Young, J. E. (1999). Cognitive therapy for personality disorders: A schema-focused approach (3rd edition). Florida, FL: Professional Resource Press.

Young, J. E. and Klosko, J. S. (2011). Hayatı yeniden keşfedin (Çev. S. Kohen ve D. Güler,). İstanbul: Psikonet Yayınları (Orijinal çalışma basım tarihi 1993).

Young, J. E., Klosko, J. S. and Weishaar, M. E. (2003). Schema therapy: Apractitioner's guide. New York: The Guilford Press.

Young, J. E., Klosko, J. S. and Weishaar, M. E. (2009). Şema terapi (Çev: T. Soylu). İstanbul: Litera Yayıncilık.

Zhao, X., Lynch Jr, J. G. and Chen, Q. (2010). Reconsidering Baron and Kenny: Myths and truths about mediation analysis. Journal of Consumer Research, 37(2), 197-206. doi: 10.1086/651257

Zimmer-Gembeck, M. J. and Collins, W. A. (2006). Autonomy Development during Adolescence. In G. R. Adams and M. D. Berzonsky (Eds.), Handbook of Adolescence, (p.175-204). Malden, MA: Blackwell.

\section{Kaynakça Bilgisi / Citation Information}

Koçak, L. ve Çelik, E. (2021). Lise öğrencilerinde öz-şefkat ile duygusal özerklik arasındaki ilişkide erken dönem uyumsuz şemaların aracı rolü. OPUS- Uluslararası Toplum Araştırmaları Dergisi, 18(Eğitim Bilimleri Özel Sayıs1), 4360-4399. DOI: 10.26466/ opus.906143. 